\title{
2 Physical and Mechanical Properties of Thermally Cracked Andesite 3 Under Pressure
}

\author{
4 Zhi Li $^{1}$ (D) Jérôme Fortin ${ }^{1} \cdot$ Aurélien Nicolas $^{1} \cdot$ Damien Deldicque $^{1} \cdot$ Yves Guéguen $^{1}$ \\ 5 Received: 6 June 2018 / Accepted: 10 March 2019 \\ 6 @ Springer-Verlag GmbH Austria, part of Springer Nature 2019
}

\section{Abstract}

8 The effects of thermal crack damage on the physical properties and rupture processes of andesite were investigated under 9 triaxial deformation at room temperature. Thermal cracking was induced by slowly heating and cooling samples. The effects 10 of heat treatment temperatures ranging between $500{ }^{\circ} \mathrm{C}$ and $1100{ }^{\circ} \mathrm{C}$ on the $\mathrm{P}$-wave velocities and on the microstructure were $\mathrm{AQ}$ 11 investigated. Then, the mechanical properties of andesite samples treated at $930{ }^{\circ} \mathrm{C}$ were investigated under triaxial stress 12 at room temperature using constant strain rate tests and confining pressures ranging between 0 and $30 \mathrm{MPa}$. Similar triaxial experiments were conducted on non-heat-treated samples. Our results show that: (1) for heat treatments at temperatures below $500{ }^{\circ} \mathrm{C}$, no significant changes in the physical properties are observed; (2) for heat treatments in the temperature range of 500-1100 ${ }^{\circ} \mathrm{C}$, crack density increases; and (3) thermal cracking has no influence on the onset of dilatancy but increases the strength of the heat-treated samples. This last result is counterintuitive, but seems to be linked with the presence of a small fraction of clay (3\%) in the non-heat-treated andesite. Indeed, for heat treatment above $500{ }^{\circ} \mathrm{C}$, some clay melting is observed and contributes to sealing the longest cracks.

Keywords Andesite $\cdot$ Thermal crack · Ultrasonic velocity $\cdot$ Crack density $\cdot$ Onset of dilatancy $\cdot$ Brittle Strength $\cdot$ Partial melting $\cdot$ Crack sealing

\section{List of Symbols}

$\varepsilon_{a} \quad$ Axial strain

$\varepsilon_{r} \quad$ Radial strain

$\varepsilon_{v} \quad$ Volumetric strain

$Q \quad$ Differential stress

$S \quad$ Total surface of crack

$\phi \quad$ Crack porosity

$P_{c} \quad$ Confining pressure

$\sigma_{1} \quad$ Maximum principle stress

$\sigma_{3} \quad$ Minimum principle stress

$\rho \quad$ Crack density

$l_{i} \quad$ Length of the $i$-th crack

$N$ Total number of cracks embedded in the representative elementary volume $V$

$V \quad$ Representative elementary volume

$E \quad$ Young's modulus of the (intact) andesite

$v \quad$ Poisson's ratio of intact andesite

$G_{\text {IC }}$ The energy release rate of andesite under mode I

$\triangle \mathrm{Zhi} \mathrm{Li}$

zli@geologie.ens.fr

1 Laboratoire de géologie, École Normale Supérieure-PSL Research University-CNRS, UMR 8538, Paris, France
$\Delta \alpha \quad$ Thermal expansion contrast between plagioclase and quartz/tridymite or glass

$\Delta T$ Temperature difference of heat treatment

$l \quad$ Grain size

w Crack half aperture

c Crack radius

$\xi \quad$ Aspect ratio

C' Onset of dilatancy

$\mu \quad$ Friction coefficient on pre-existing flaws

$K_{\text {IC }} \quad$ Fracture toughness

$a \quad$ Length of pre-existing flaws

$D_{0} \quad$ Initial damage

$N_{V} \quad$ Number of sliding cracks initially

\section{Introduction}

The physical properties and mechanical behavior of andesite are of interest for the understanding of several natural processes and for engineering design. Natural processes include ground deformation due to magma rising below volcanoes (Jaupart 1998; Costa et al. 2009; Heap et al. 2014), eruption activity and cessation of dikes (Gudmundsson 2006, 2011;

\begin{tabular}{|l|l|l|l|l|}
\hline Journal : Large 603 & Article No : 1785 & Pages : 20 & MS Code : RMRE-D-18-00808 & Dispatch : 19-3-2019 \\
\hline
\end{tabular}


Browning et al. 2015), or fault activity in volcano systems (Rowland and Sibson 2001). Industrial contexts are geothermal reservoir engineering (Siratovich et al. 2014) and $\mathrm{CO}_{2}$ sequestration (Trias et al. 2017).

In volcanic areas, where hot fluids circulate, temperature is a parameter that should be taken into account when investigating mechanical behavior. Temperature variations can induce intragranular cracks and intergranular cracks or even melting of the rock (Friedman et al. 1979; Wong 1989), leading to large changes in the microstructure. A common way to investigate the effect of temperature on the mechanical behavior is to use heat-treated samples.

Many studies have been performed on the role of thermal effects in the mechanical behavior of igneous rocks, including intrusive and extrusive rocks (Heap et al. 2016, 2014, 2015; Vinciguerra et al. 2005; Fortin et al. 2011; Stanchits et al. 2006; Meredith et al. 2005; Wang et al. 2013). Increasing temperature can modify fluid transport properties (Vinciguerra et al. 2005; Nasseri 2009; Faoro 2013; Darot 2000; Geraud 1994), elastic wave velocities (Walsh 1965; Nasseri 2007), and mechanical properties (Faulkner et al. 2003; Wang et al. 2013). Thermal cracking has been shown to weaken different rocks, including granite (Homand-Etienne and Houpert 1989; Chaki et al. 2008), gabbro (Keshavarz et al. 2010), calcarenite (Brotóns et al. 2013), and carbonate (Sengun et al. 2014). P-wave velocity changes due to thermal cracking are expected. Such changes are important for seismic tomography inversion of volcano systems and may be useful for investigating magma chamber activity and dike eruption. According to Griffith et al. (2017) and Browning et al. (2016), more cracks are created during the cooling stage than during the heating stage.

In contrast with intrusive rocks, extrusive rocks have a different structure resulting from fast cooling: a fine groundmass and phenocrysts. Note that the ultrasonic velocities and transportation properties of andesite have been investigated in previous studies (Fortin et al. 2011; Fatquharson et al. 2015; Heap et al. 2014, 2015; Siratovich et al. 2015; Heap and Kennedy 2016).

The selected rock for this study is an andesite from Guadeloupe, France. Guadeloupe is located in the Lesser Antilles arc. This arc results from the subduction of the North American Plate under the Caribbean Plate (Bouysse et al. 1990). The Bouillante (Guadeloupe, France) geothermal power plant has been operating for 30 years (Jaud and Lamethe 1985). GEOTREF (A project aimed at improving understanding fractured geothermal reservoirs) is planning a new geothermal project in the area from which the samples were taken. Faults and active fluids are present in the volcano system and cause significant seismicity activity (Feuillet et al. 2001, 2002). Because induced seismicity is possible during geothermal exploration, it is important to systematically determine the geomechanical behavior and to characterize its evolution resulting from thermal stresses. This paper aims to investigate the effect of heat treatment on the mineralogical composition, microstructural parameters (porosity, crack density), and petrophysical parameters (permeability, elastic wave velocities) of andesite. For this purpose, we selected an andesitic block from a quarry located in Guadeloupe, France, and samples were heat-treated at different temperatures. Then, petrophysical and mechanical properties were measured.

\section{Materials and Methods}

\subsection{Materials}

\subsubsection{Rock Samples}

The samples of andesite were cored from a single block, which was obtained from a quarry located in Déhaies (Guadeloupe, France). Cylindrical samples were cored with diameters of $40 \mathrm{~mm}$ and lengths of $80 \mathrm{~mm}$. No bedding related to volcanic features was identified in the block. After coring, boundary surfaces were polished to ensure smooth horizontal surfaces.

The samples have a mean density of $2670 \mathrm{~kg} / \mathrm{m}^{3}$, and the porosity varies between $1.5 \%$ and $2.3 \%$ with a mean porosity of $1.9 \%$. The porosity is estimated by comparing the weight of a water-saturated sample with the weight of the same sample dried under a vacuum at $40{ }^{\circ} \mathrm{C}$ for 4 days. The permeability of the non-heat-treated andesite is approximately $10^{-21} \mathrm{~m}^{2}$. The P-wave velocity of the non-heat-treated andesite samples is $5400 \mathrm{~m} / \mathrm{s}$ with a measurement error of $200 \mathrm{~m} / \mathrm{s}$.

The andesite is composed of a fine groundmass with large phenocrysts (Fig. 1). The matrix is composed of quartz and plagioclase $(50-60 \%)$. The mean grain size of the matrix is $2 \mu \mathrm{m}$. Phenocrysts are plagioclase $(25-35 \%)$, pyroxene (15-20\%), and oxides (4-5\%). The mean grain size of phenocrysts is $100 \mu \mathrm{m}$ (Fig. 1).

Figure 1 shows that this andesite is naturally microcracked. Cracks can be observed inside the phenocrysts (Fig. 1c). Figure 2 also shows that the andesite sample has a few long cracks in the matrix, with lengths on the order of $300 \mu \mathrm{m}-500 \mu \mathrm{m}$.

\subsubsection{Procedure of The Heat Treatment}

Samples were heat treated to four different temperatures: $500{ }^{\circ} \mathrm{C}, 800{ }^{\circ} \mathrm{C}, 930{ }^{\circ} \mathrm{C}$, and $1100{ }^{\circ} \mathrm{C}$. Samples were placed in a programmable Meker MHT-3 furnace (Nicolas et al. 2016), and the temperature was increased at a rate of $140{ }^{\circ} \mathrm{C} / \mathrm{h}$ to the target temperature. The furnace atmosphere was not controlled by air-oxygen fugacity. The target
123 


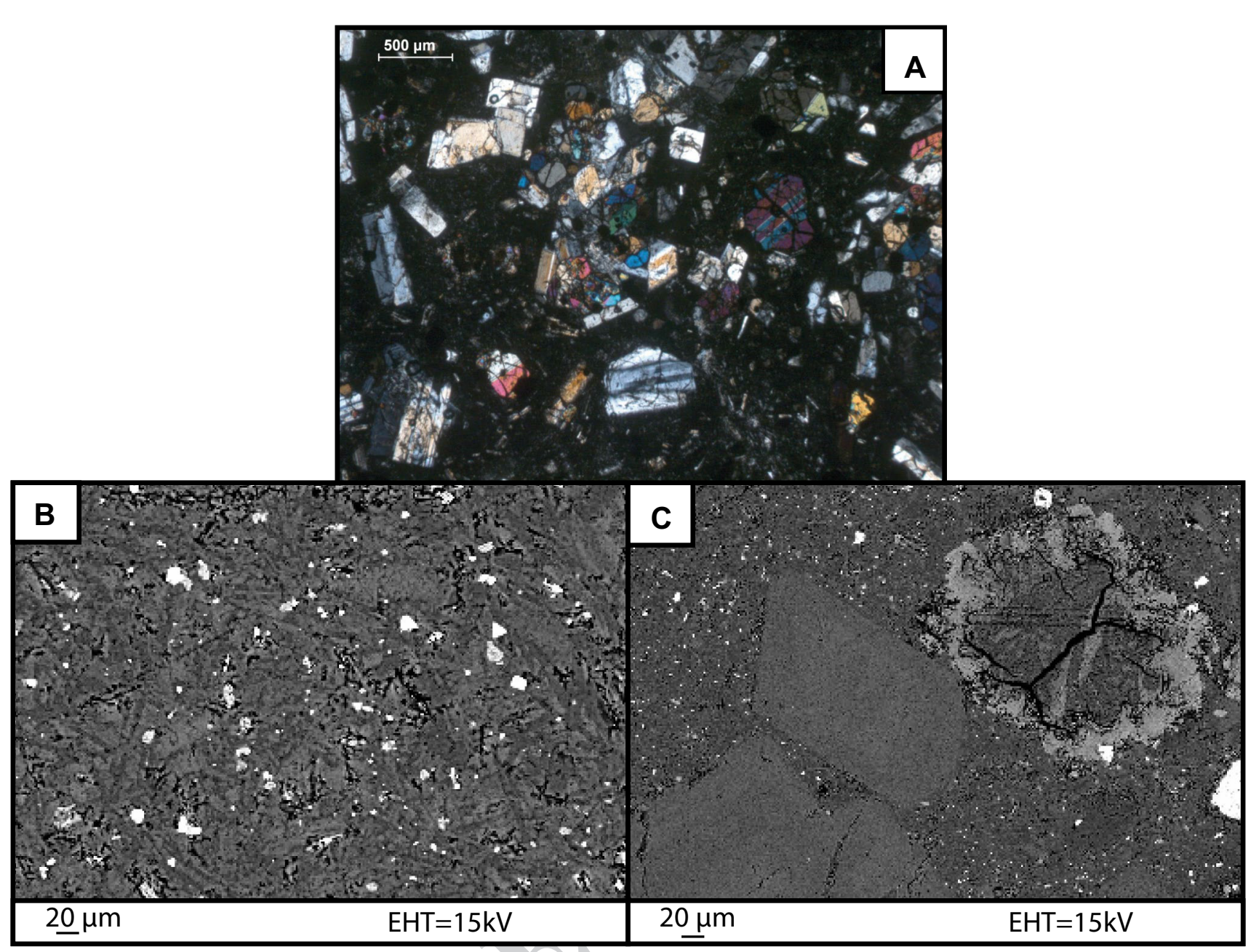

Fig. 1 a SEM images of a non-heat-treated andesite sample at low magnitude. b High magnification view of the matrix. c High magnification view of the phenocrysts

\section{Intact Andesite}



Fig. 2 Cracks in the matrix. The longest cracks have a length of 300-500 $\mu \mathrm{m}$

\begin{tabular}{|l|l|l|l|l|}
\hline Journal : Large 603 & Article No : 1785 & Pages : 20 & MS Code : RMRE-D-18-00808 & Dispatch : 19-3-2019 \\
\hline
\end{tabular}


temperature was held constant for $2 \mathrm{~h}$. Samples were slowly cooled to room air temperature. The cooling rate was controlled by the thermal inertia of the oven and remained slow ( $\sim 10 \mathrm{~h}$ to decrease from $930{ }^{\circ} \mathrm{C}$ to room temperature). The effects of the heat treatment amplitude on the petrophysical properties of the andesite are presented in Sect. 3.1. The particular temperature of $930^{\circ} \mathrm{C}$ was selected for a detailed triaxial deformation test. This temperature corresponds to that of the second magma chamber temperature in La Soufière, Guadeloupe (Villemant et al. 2014), which is where the dikes begin (Villemant 2014). The mechanical properties of the heat-treated andesite samples are investigated and compared to the mechanical properties of the non-heat-treated samples.

\subsection{Experimental Methods}

\subsubsection{Experimental Apparatus}

Triaxial deformation experiments are performed on the triaxial cell installed at the Laboratoire de Géologie at École Normale Supérieure in Paris (Fig. 14 in Appendix 1). The axial load is applied by an axial piston with a maximum load of $680 \mathrm{MPa}$ and is measured with a sensor with an accuracy of approximately $10^{-3} \mathrm{MPa}$. The confining pressure is applied by a volumetric servo pump that can provide pressure up to a maximum of $100 \mathrm{MPa}$ and is measured by a pressure transducer with an accuracy of $10^{-3} \mathrm{MPa}$ (OugierSimonin et al. 2011; Nicolas et al. 2016). The pressure-conducting medium is silicone oil.

\subsubsection{Strain and Ultrasonic Instrumentation}

Four groups of strain gauges are glued at different positions directly on the sample. (Fig. 15 in Appendix 1). Each group is composed of one axial gauge and one radial gauge. Strain gauges Tokyo Sokki TML FCB 2-11 are employed. The axial strain $\varepsilon_{a}$, and radial strain $\varepsilon_{r}$ are both averaged across the four strain gauges in each orientation. The volumetric strain is deduced as $\varepsilon_{v}=\varepsilon_{a}+2 \varepsilon_{r}$. Neoprene tubing is used to separate the sample from the oil of the confining medium. Then, 12 P-wave sensors (PI 255 PI Ceramics, $1 \mathrm{MHz}$ resonance frequency) and four polarized S-wave sensors (Shear PZT plate) are glued directly on the surface of the rock and sealed with a two-component epoxy (Fig. 15 in Appendix 1). The network of ultrasonic sensors used allows us to record (i) acoustic emissions (passive mode) and (ii) the evolution of the ultrasonic velocities in different directions (active mode). For the ultrasonic wave velocity survey, a $250 \mathrm{~V}$ high-frequency signal is pulsed every 2 min on each sensor while the others are recording. In passive mode, these sensors can record the acoustic emissions (AE) that take place in the sample. The AEs are amplified at $40 \mathrm{~dB}$ and can be discretely recorded with a maximum rate of $12 \mathrm{AE} / \mathrm{s}$. (Schubnel et al. 2006, 2007; Brantut et al. 2011; OugierSimonin et al. 2011; Nicolas et al. 2016).

\subsubsection{Experimental Procedure}

For all the samples, the P-ultrasonic wave velocity is measured at room temperature and atmospheric pressure. Permeability is measured with water using transient pulse or steady flow methods at $2.5 \mathrm{MPa}$ effective confining pressure. For non-heat-treated samples and samples heat-treated to $500{ }^{\circ} \mathrm{C}$, permeability is measured using the transient pulse (Brace et al. 1966) (two symmetrical measures are performed by switching the flow direction in the sample); for samples heat-treated to $800{ }^{\circ} \mathrm{C}$ and $930^{\circ} \mathrm{C}$, permeability is measured with steady state flow.

For non-heat-treated andesite samples and heat-treated (at $930{ }^{\circ} \mathrm{C}$ ) andesite samples, experiments are performed under dry conditions at room temperature, with confining pressures of 5, 15 and $30 \mathrm{MPa}$ (non-heat treated samples) and 0,15 and $30 \mathrm{MPa}$ (heat-treated samples). Differential loading is applied up to peak stress using a controlled constant strain loading rate of $10^{-6} / \mathrm{s}$. During triaxial deformation, ultrasonic measurements are made on all samples every $2 \mathrm{~min}$.

In the following, we adopt the convention that compressive stresses and compactive strains are positive. The dif- $\mathbf{A Q}_{4} 9$ ferential stress is noted by $Q=\sigma_{1}-\sigma_{3}$, and the mean stress 230 by $P=\left(\sigma_{1}+2 \sigma_{3}\right) / 3$, where $\sigma_{1}$ and $\sigma_{3}=P_{c}$ are the vertically applied (maximum) stress and the confining pressure (minimum), respectively.

\section{Results}

\subsection{Properties of Samples Heat-Treated at Different Temperatures}

\subsubsection{P-Wave Velocity, Crack Density and Permeability}

The samples were heat-treated at different temperatures: $500{ }^{\circ} \mathrm{C}, 850{ }^{\circ} \mathrm{C}, 930{ }^{\circ} \mathrm{C}$ and $1100{ }^{\circ} \mathrm{C}$. The evolution of the $\mathrm{P}$-wave velocity and permeability as functions of the temperature of the heat treatment are shown in Fig. 3. In addition, we invert the P-wave velocity to obtain the crack density, as defined by $\rho=\sum_{N} \frac{l_{i}^{3}}{V}$, where $l_{i}$ is the length of the $i$-th crack and $N$ is the total number of cracks embedded in the representative elementary volume $V$. When the crack length is smaller than the wavelength, effective medium theory is an appropriate method (Ougier-Simonin et al. 2010). The effective elastic properties are mainly controlled by cracks (Gueguen and Kachanov 2011). A noninteractive assumption is employed (Kachanov 1994). Noninteractive effective medium theory has been shown to be valid when cracks

0

31




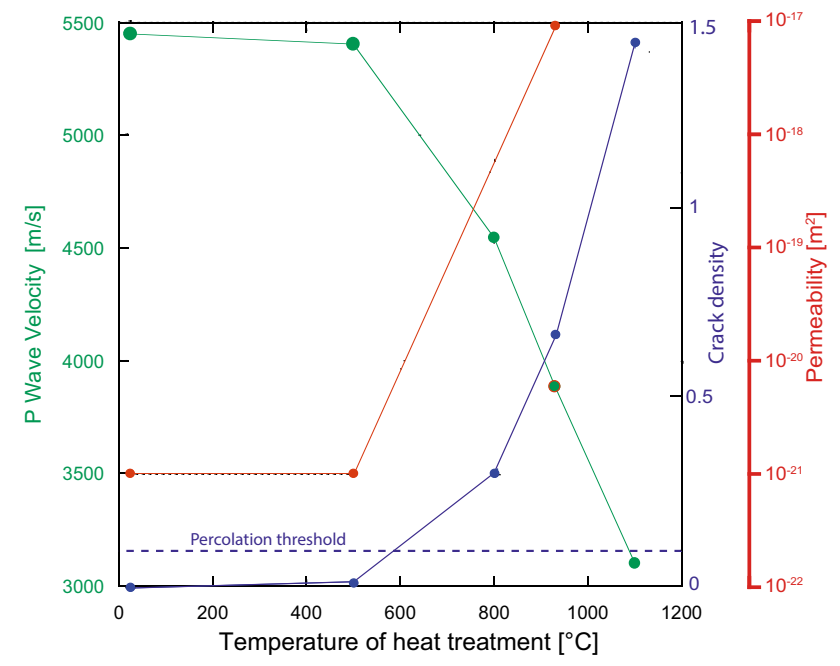

Fig. 3 P-wave velocity (green curve), crack density (blue curve). Permeability (red curve). Note that the percolation threshold (crack density of 0.1 ) is indicated as a blue dashed line

are distributed randomly and crack density does not exceed
0.2-0.3 (Kachanov 1994; Sayers and Kachanov 1995; Gueguen and; Sarout 2009). The details of the inversion in crack density are given in the appendix "Crack density inversion method-Isotropic case" (Ougier-Simonin et al. 2010; Mallet et al. 2014; Fortin et al. 2011; Nicolas et al. 2016)

A small decrease in the P-wave velocity of $70 \mathrm{~m} / \mathrm{s}(1.3 \%)$ is recorded (Fig. 3) for a heat treatment of $500{ }^{\circ} \mathrm{C}$. However, the decrease reaches $1000 \mathrm{~m} / \mathrm{s}(18 \%)$ for a temperature of $800{ }^{\circ} \mathrm{C}$ and $2250 \mathrm{~m} / \mathrm{s}(41 \%)$ for a temperature of $1100^{\circ} \mathrm{C}$, indicating a major change at approximately $500^{\circ} \mathrm{C}$, which should be associated with a significant change in microstructure. The crack density inverted from the P-wave velocity increases from 0.01 for a heat treatment of $500{ }^{\circ} \mathrm{C}$ to 1.4 for a heat treatment of $1100{ }^{\circ} \mathrm{C}$. This last value is outside the range in which effective medium theory is valid. However, the value points to very intense cracking. The induced crack density reaches the percolation threshold of 0.1 (Guéguen and Dienes 1989) for a heat treatment between $500{ }^{\circ} \mathrm{C}$ and $800{ }^{\circ} \mathrm{C}$. This result is in good agreement with the permeability evolution, which shows no change below $500{ }^{\circ} \mathrm{C}$, but shows an increase by four orders of magnitude for a heat treatment of $930{ }^{\circ} \mathrm{C}$ (Fig. 3).

\subsubsection{Microstructural Observations of The Heat-Treated Samples}

The microstructures are shown in Fig. 4. In the sample heattreated at $500{ }^{\circ} \mathrm{C}$ (Fig. 4a, b), few cracks can be observed. In the samples heated at $800{ }^{\circ} \mathrm{C}$ (Fig. 4c, d) and $930{ }^{\circ} \mathrm{C}$ (Fig. 4e, f), cracks surrounding the large inclusions with lengths of 50-200 $\mu \mathrm{m}$ can be observed, including intergranular and intragranular cracks. Small cracks begin to appear in the matrix. Partial melting occurs above $500{ }^{\circ} \mathrm{C}$; the details and effects of partial melting are presented in Sect. 3.2. The sample treated at $1100{ }^{\circ} \mathrm{C}$ shows the highest crack density (Fig. 4g, h). In particular, in the matrix (Fig. 4h), the number of cracks with lengths ranging between $1 \mu \mathrm{m}$ and $20 \mu \mathrm{m}$ is greatly increased, and most cracks are located at the boundaries of the crystal grains of quartz, tridymite, and plagioclase. Overall, the evolution of the microstructure is in good agreement with the evolution of the P-wave velocity and the permeability (Fig. 3).

\subsection{Mineralogical Effects of Heat Treatment on Andesite}

\subsubsection{Mineralogical Composition}

The mineralogical compositions of non-heat-treated andesite samples and heat-treated andesite samples were analyzed with EBSD (electron backscatter diffraction) and XRD (X-ray diffraction).

For non-heat-treated andesite samples, the ratio of different phases is shown in Table 1. A more detailed composition is given in Appendix A. The non-heat-treated andesite sample is composed of $70.8 \%$ plagioclase (including bytownite, sanidine and albite), $14.1 \%$ pyroxene (including diopside, hypersthene and augite), 9.2\% other silicates (including tridymite and quartz) and $2.5 \%$ iron oxides. The clay content is $3.4 \%$, mainly smectite due to plagioclase alteration $\mathbf{A Q 6} \quad 7$ (Table 2).

The mineralogical composition is slightly changed for samples heat-treated at $500^{\circ} \mathrm{C}$ and $930{ }^{\circ} \mathrm{C}$. In particular, the smectite (clay) disappears, and another form of clay appears: illite. The samples heat treated at $930{ }^{\circ} \mathrm{C}$ and $1100^{\circ} \mathrm{C}$ are similar (disappearance of smectite); in addition, the proportion of plagioclase decreases by $2 \%$, whereas the proportion of silicate increases by $2 \%$, but this last result could be due to the heterogeneity existing in the samples. Irreversible dehydration and loss of swelling properties of smectite have been shown (e.g., Greene-Kelly 1953; Russel and Farmer 1964) to occur at temperatures between $350{ }^{\circ} \mathrm{C}$ and $550{ }^{\circ} \mathrm{C}$, while dihydroxylation of smectite occurs at temperatures between $550{ }^{\circ} \mathrm{C}$ and $800{ }^{\circ} \mathrm{C}$ (Malek et al. 1997).

\subsubsection{Partial Melting}

The non-heat-treated andesite contains smectite (clay) related to the alteration of plagioclase, the smectite is mainly located in the vicinity of plagioclase (Fig. 5a).

As the heat treatment reaches $930{ }^{\circ} \mathrm{C}$, partial melting is observed in the samples from SEM images (Fig. 5a). Glass is visible in the porosity (Fig. 5b). Smectite melting results in voids with sizes ranging from $5-10 \mu \mathrm{m}$, mainly located
296

297

298

299

300

301

302

303

304

305

306

\begin{tabular}{|l|l|l|l|l|}
\hline Journal : Large 603 & Article No : 1785 & Pages : 20 & MS Code : RMRE-D-18-00808 & Dispatch : 19-3-2019 \\
\hline
\end{tabular}


Fig. 4 SEM pictures of andesite samples heat-treated to $500{ }^{\circ} \mathrm{C}$, $800{ }^{\circ} \mathrm{C}, 930^{\circ} \mathrm{C}$ and $1100^{\circ} \mathrm{C}$
$500{ }^{\circ} \mathrm{C}$



$800^{\circ} \mathrm{C}$
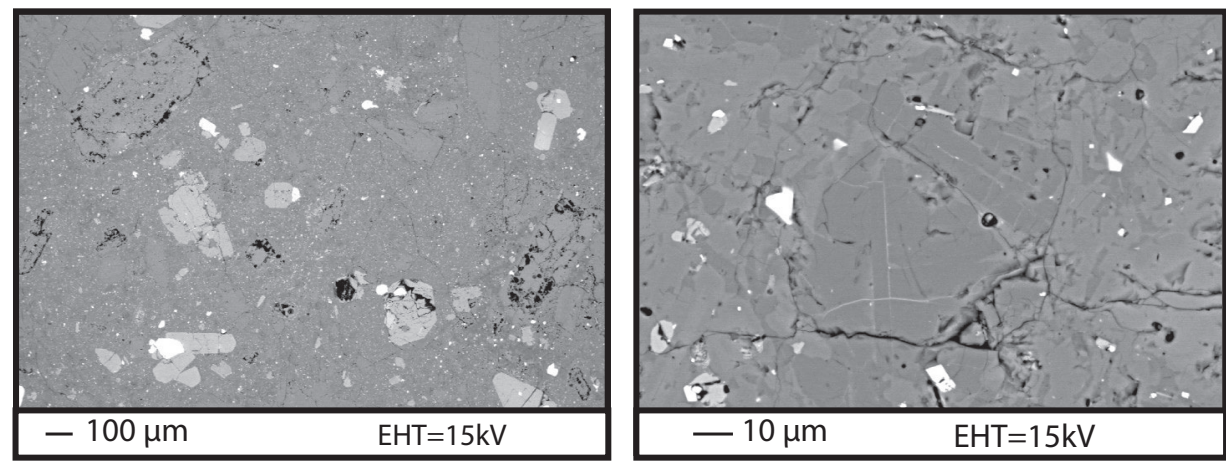

$930^{\circ} \mathrm{C}$
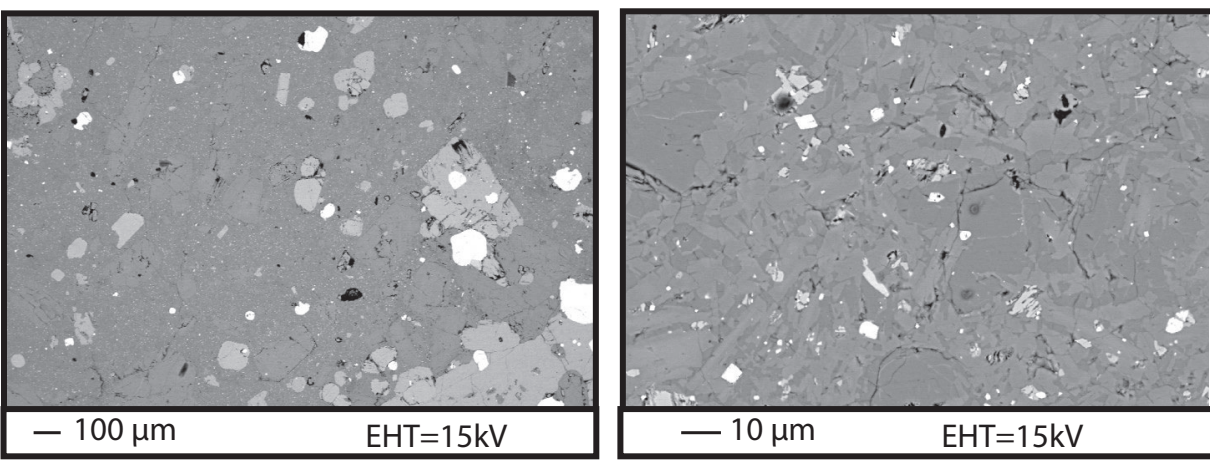

$1100^{\circ} \mathrm{C}$
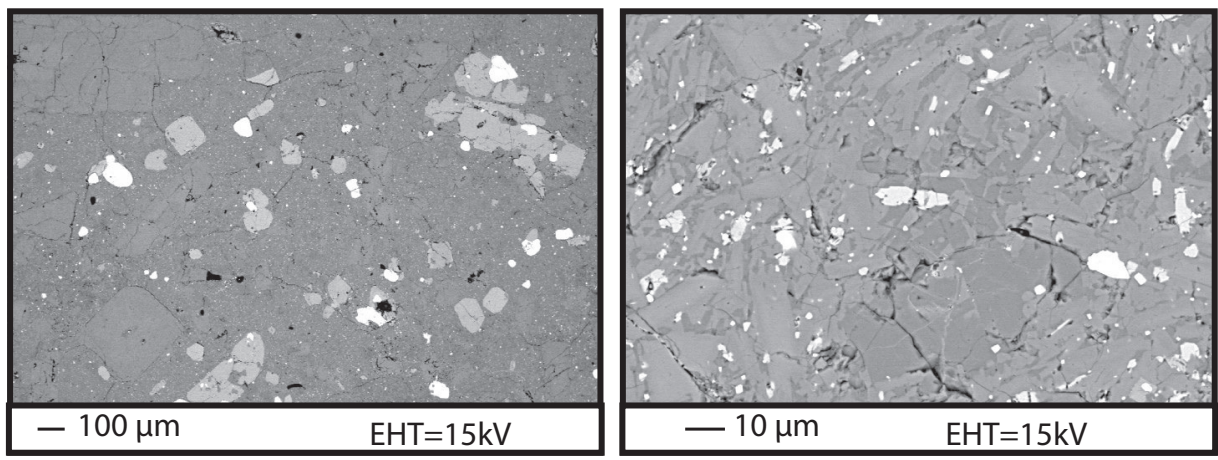
Table 1 Chemical composition of andesite samples heat treated to different temperatures

\begin{tabular}{lllllll}
\hline Sample & Plagioclase(\%) & Pyroxene (\%) & Silicon (\%) & Ironoxides (\%) & Smectite (\%) & Illite (\%) \\
\hline Andesite & 70.8 & 14.1 & 9.2 & 2.5 & 3.4 & 0.0 \\
HT500 & 70.9 & 15.5 & 7.8 & 2.2 & 0.0 & 3.5 \\
Andesite HT930 & 73.2 & 14.4 & 8.0 & 1.9 & 0.0 & 2.5 \\
Andesite HT 1100 & 68.7 & 13.6 & 11.0 & 2.9 & 0.0 & 3.9 \\
\hline
\end{tabular}

Table 2 Chemical composition of andesite samples heat treated to different temperatures

\begin{tabular}{llllll}
\hline Classification & Mineral (\%) & Andesite (\%) & $\begin{array}{l}\text { Andesite 500 } \\
(\%)\end{array}$ & $\begin{array}{l}\text { Andesite 930 } \\
(\%)\end{array}$ & $\begin{array}{l}\text { Andesite } \\
1100(\%)\end{array}$ \\
\hline Plagioclase & Bytownite & 7.4 & 24.7 & 23 & 14.8 \\
& Sadine & 10.6 & 11.4 & 12.7 & 14.3 \\
& Albite & 52.8 & 34.8 & 37.5 & 39.6 \\
Pyroxene & Diopside & 1.7 & 2.3 & 3.3 & 0.8 \\
& Hypersthene & 6.4 & 8.4 & 9.1 & 6.4 \\
& Augite & 6.1 & 4.8 & 2.1 & 6.5 \\
Silicon & Tridymite & 8.0 & 7.2 & 5.0 & 9.2 \\
& SiO2 & 1.2 & 0.6 & 3.1 & 0.8 \\
Iron-oxides & Ilmentite & 0.2 & 0.0 & 0.0 & 1.9 \\
& Magnetite & 2.4 & 2.2 & 1.9 & 0.9 \\
Clay & Smectite & 3.4 & 0.0 & 0.0 & 0.0 \\
& Illite & 0.0 & 3.5 & 2.5 & 3.9 \\
\hline
\end{tabular}

near plagioclase (where the smectite was located). In the matrix, small pores of $0.5-1 \mu \mathrm{m}$ are also observed, mostly at the boundaries of oxides. These pores may also be due to the melting of smectite.

\subsection{Triaxial Deformation of Non-Heat-Treated Andesite and Heat-Treated Andesite}

\subsubsection{Stress-Strain Behavior of Non-Heat-Treated Andesite}

Triaxial deformation tests were performed at confining pressures of $5 \mathrm{MPa}, 15 \mathrm{MPa}$ and $30 \mathrm{MPa}$ under dry conditions at room temperature. The differential stress and mean stress are plotted versus axial strain and volumetric strain, respectively, in Fig. 6.

The samples under confining pressures varying between $5 \mathrm{MPa}$ and $30 \mathrm{MPa}$ are deformed in the brittle regime. The differential stress reaches a peak stress followed by macroscopic failure. The peak stress is observed to increase with confining pressure: the maximum differential stress increases by $20 \%$ as the confining pressure increases from $5 \mathrm{MPa}$ to $15 \mathrm{MPa}$ and increases by $27 \%$ as the confining pressure increases from $5 \mathrm{MPa}$ to $30 \mathrm{MPa}$. Note that at the beginning of the loading, the stress-strain curves (Fig. 6) are almost linear, which indicates that the number of preexisting crack is very small.

Another result of interest is the identification of the D' point, which is the point where volumetric strain reverses
(Fig. 6). Beyond D', dilatancy dominates over compaction (Heap et al. 2014). The differential stress for D' increases as the confining pressure is increased from $5 \mathrm{MPa}$ to $30 \mathrm{MPa}$. The stress state of D' increases by $22 \%$ as the confining pressure increases from $5 \mathrm{MPa}$ to $15 \mathrm{MPa}$ and increases by $50 \%$ as the confining pressure increases from $5 \mathrm{MPa}$ to $30 \mathrm{MPa}$.

\subsubsection{Ultrasonic Velocity Evolution of Non-Heat-Treated Andesite}

The P-wave velocity evolution during the triaxial deformation of andesite samples under confining pressures of $5 \mathrm{MPa}$, $15 \mathrm{MPa}$ and $30 \mathrm{MPa}$ is shown in Fig. 7b. In Fig. 7a, the rays of the different P-wave velocities are plotted. The P-wave velocities were measured at four fixed angles $\left(0^{\circ}, 22^{\circ}, 48^{\circ}\right.$, $\left.53^{\circ}\right)$. During the first phase of loading, in the quasi-elastic regime, the $\mathrm{P}$-wave velocity is almost constant. This observation agrees with the almost linear stress-strain curve and indicates that the amount of crack porosity is very low (Walsh 1965). The P-wave velocity decreases at the onset of dilatancy, marked as point C' (Brace et al. 1966), as cracks nucleate and propagate. The stress state C' corresponds to the beginning of the P-wave velocity decrease (acoustic data) and to the stage where the volumetric strain curve deviates from linearity (mechanical data) (Brace et al. 1966), as shown in Fig. $7 b$.

\begin{tabular}{|l|l|l|l|l|}
\hline Journal : Large 603 & Article No : 1785 & Pages : 20 & MS Code : RMRE-D-18-00808 & Dispatch : 19-3-2019 \\
\hline
\end{tabular}


Fig. 5 a Partial melting, in samples heat-treated at $930{ }^{\circ} \mathrm{C}$ Melting occurs at the boundaries of the phenocrysts, i.e., where the clay (smectite) is located. b Glass is spotted in the porosity, indicating partial melting
A Intact Andesite Sample
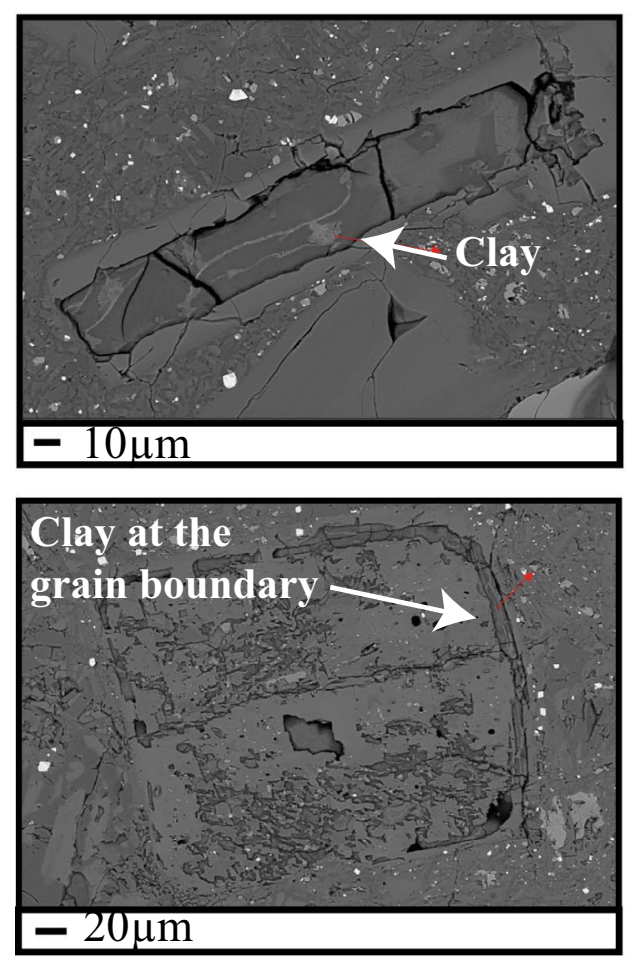

$-20 \mu \mathrm{m}$

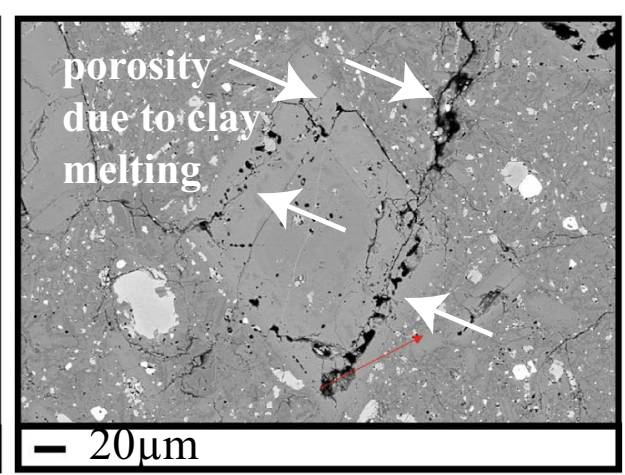

B
Andesite Heat treated to $930^{\circ} \mathrm{C}$

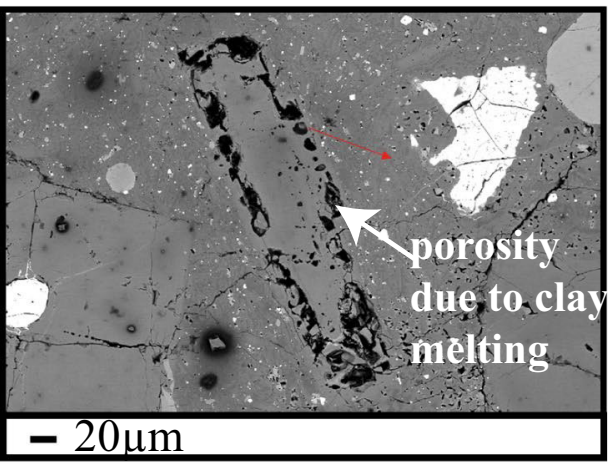

$-20 \mu \mathrm{m}$






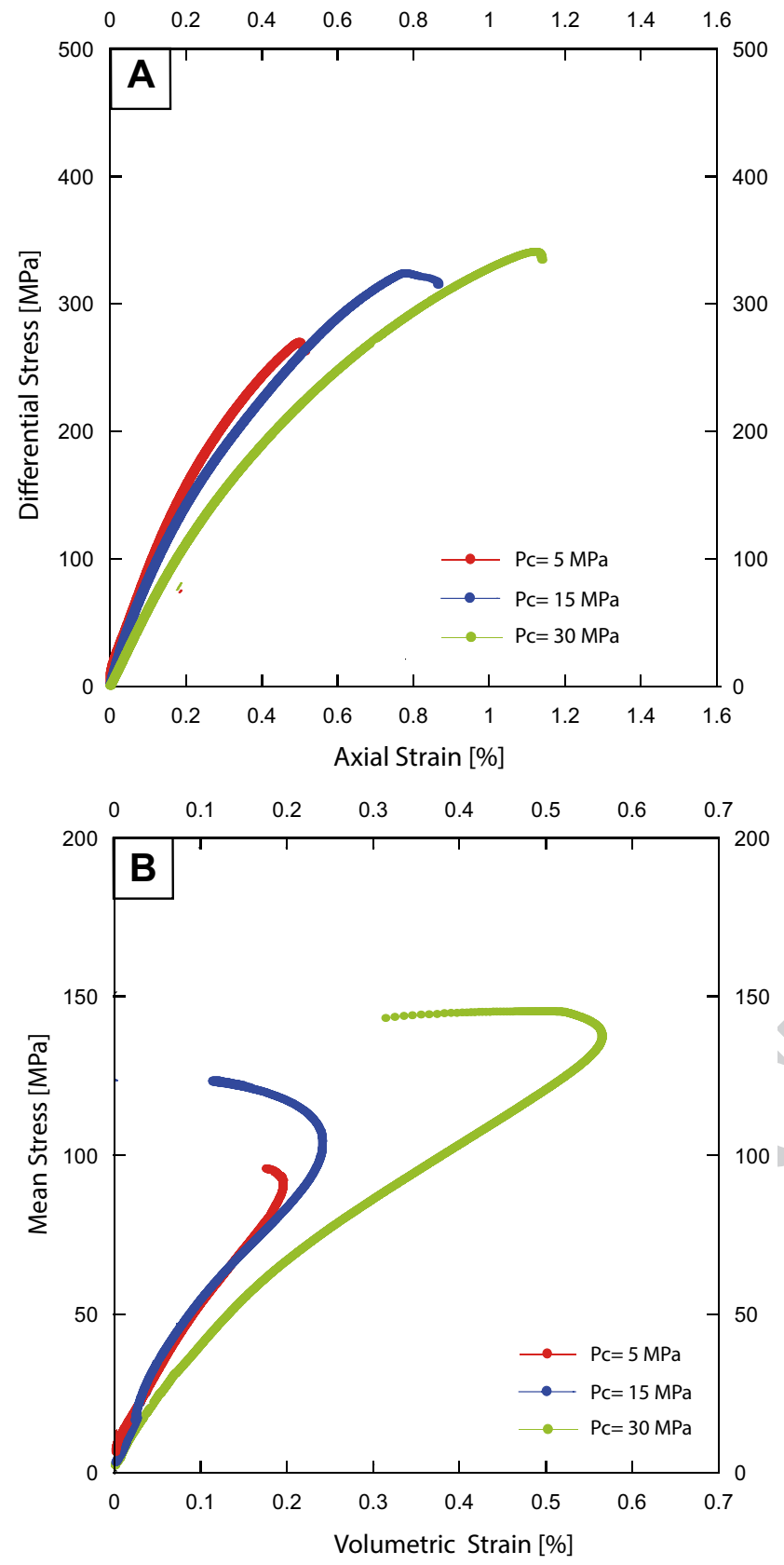

Fig. 6 Conventional triaxial experiments on non-heat-treated andesite samples under dry condition. a Differential stress versus axial strain under confining pressure of $5 \mathrm{MPa}, 15 \mathrm{MPa}$ and $30 \mathrm{MPa}$. b Mean stress versus volumetric strain
For the three experiments, P-wave anisotropy is observed as the sample is deformed, with the $\mathrm{P}$-wave velocity for rays at $90^{\circ}$ with respect to the axial stress decreasing most.

\subsubsection{Stress-Strain Relation of Heat-Treated Andesite}

Triaxial experiments were performed on andesite samples heat-treated (at $930{ }^{\circ} \mathrm{C}$ ) under confining pressures of $0 \mathrm{MPa}$ (ultrasonic sensor and strain gauges are glued directly on the sample, measured inside the triaxial cell), $15 \mathrm{MPa}$ and $30 \mathrm{MPa}$ under dry conditions. The differential stress and mean stress are plotted versus axial strain and volumetric strain, respectively, in Fig. 8.

As in the case of the non-heat-treated andesite samples, the mechanical behavior of the heat-treated samples is brittle. The peak stress increases by $56 \%$ as the confining pressure increases from $0 \mathrm{MPa}$ to $15 \mathrm{MPa}$ and by $200 \%$ as the confining pressure increases from $0 \mathrm{MPa}$ to $30 \mathrm{MPa}$.

A clear effect of pre-existing crack closure is shown on the stress-strain curve in Fig. 8, which is denoted by the concave curve at the beginning of loading.

\subsubsection{Ultrasonic Velocity Evolution of Heat-Treated Andesite}

The P-wave velocity evolution during the triaxial deformation of heat-treated andesite samples under confining pressures of $0 \mathrm{MPa}, 15 \mathrm{MPa}$ and $30 \mathrm{MPa}$ is shown in Fig. 9. In Fig. 9, the evolution of $\mathrm{P}$-wave velocities along different traces from $0^{\circ}$ to $53^{\circ}$ (Fig. 7.a) is plotted. A clear difference can be observed in comparison with Fig. 7b for heat-treated samples, the P-wave velocity increases at the beginning of loading, indicating the closure of pre-existing cracks (Stage I). This observation agrees with the stress-strain curve of heat-treated andesite samples, which is concave at the beginning of loading.

During stage II (from C' to D'), the P-wave velocity reaches a plateau. There is competition between pre-existing crack closure and new crack nucleation and propagation. The onset of dilatancy (point $C^{\prime}$ ) corresponds to new crack nucleation. Point $C^{\prime}$ is determined from both acoustic data and mechanical data, as shown in Fig. 9. Regarding the acoustic data, point C' corresponds approximately to the stage where the radial P-wave velocity stops increasing. At stage III, from point D' to the failure point, a clear decrease in P-wave velocities is observed as well as clear P-wave anisotropy indicating the propagation and nucleation of mainly axial cracks.

\section{Discussion}

\subsection{Effect of The Heat Treatment on The Crack Density}

\subsubsection{Heat Treatment and Crack Density}

Cracks formed in heat-treated andesite are mainly due to thermal stresses because minerals or aggregates have different thermal expansion coefficients (Friedrich and Wong 1986). According to theoretical considerations based on

\begin{tabular}{|l|l|l|l|l|}
\hline Journal : Large $\mathbf{6 0 3}$ & Article No : 1785 & Pages : 20 & MS Code : RMRE-D-18-00808 & Dispatch : 19-3-2019 \\
\hline
\end{tabular}


A

$\sigma_{1}$

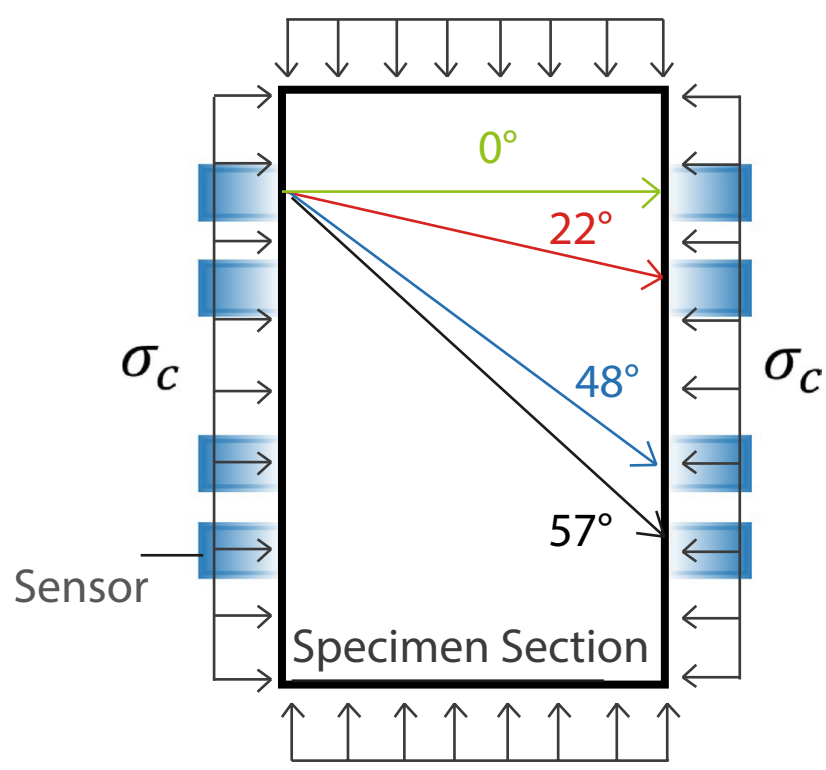

B
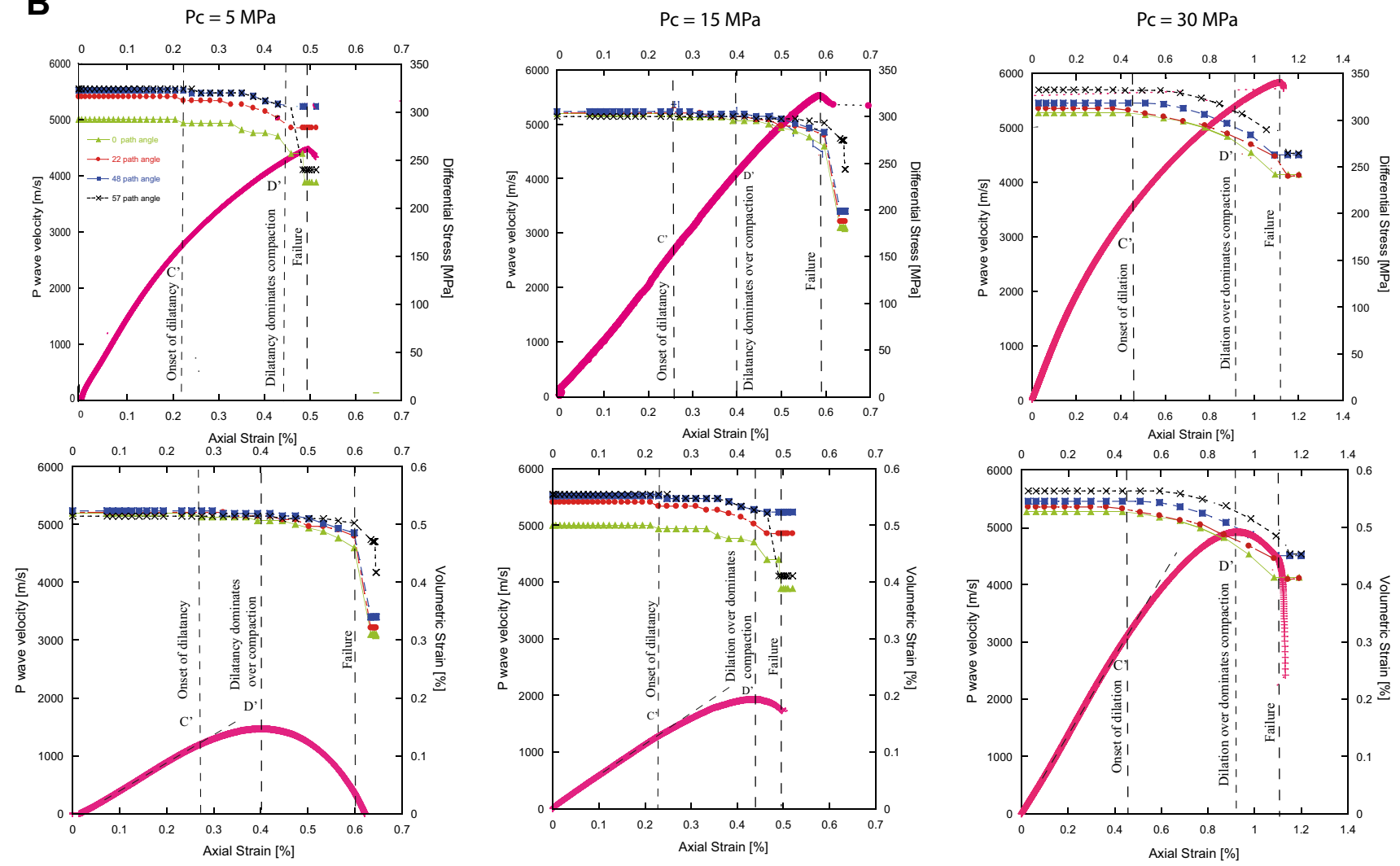

Fig. 7 a Sketch illustrating how P-wave velocities are measured with different angles with respect to $\sigma_{1}$. b P-wave velocity and differential stress measured during triaxial deformation experiments on intact andesite samples under confining pressure of $5 \mathrm{MPa}, 15 \mathrm{MPa}$ and $30 \mathrm{MPa}$. P-wave velocity and differential stress are plotted versus axial strain. P-wave velocity and volumetric strain are plotted versus axial strain. The point C' indicates the onset of dilatancy, D' indicates dilation over dominates compaction, failure is marked

\begin{tabular}{|l|l|l|l|l|}
\hline Journal : Large 603 & Article No : 1785 & Pages : 20 & MS Code : RMRE-D-18-00808 & Dispatch : 19-3-2019 \\
\hline
\end{tabular}



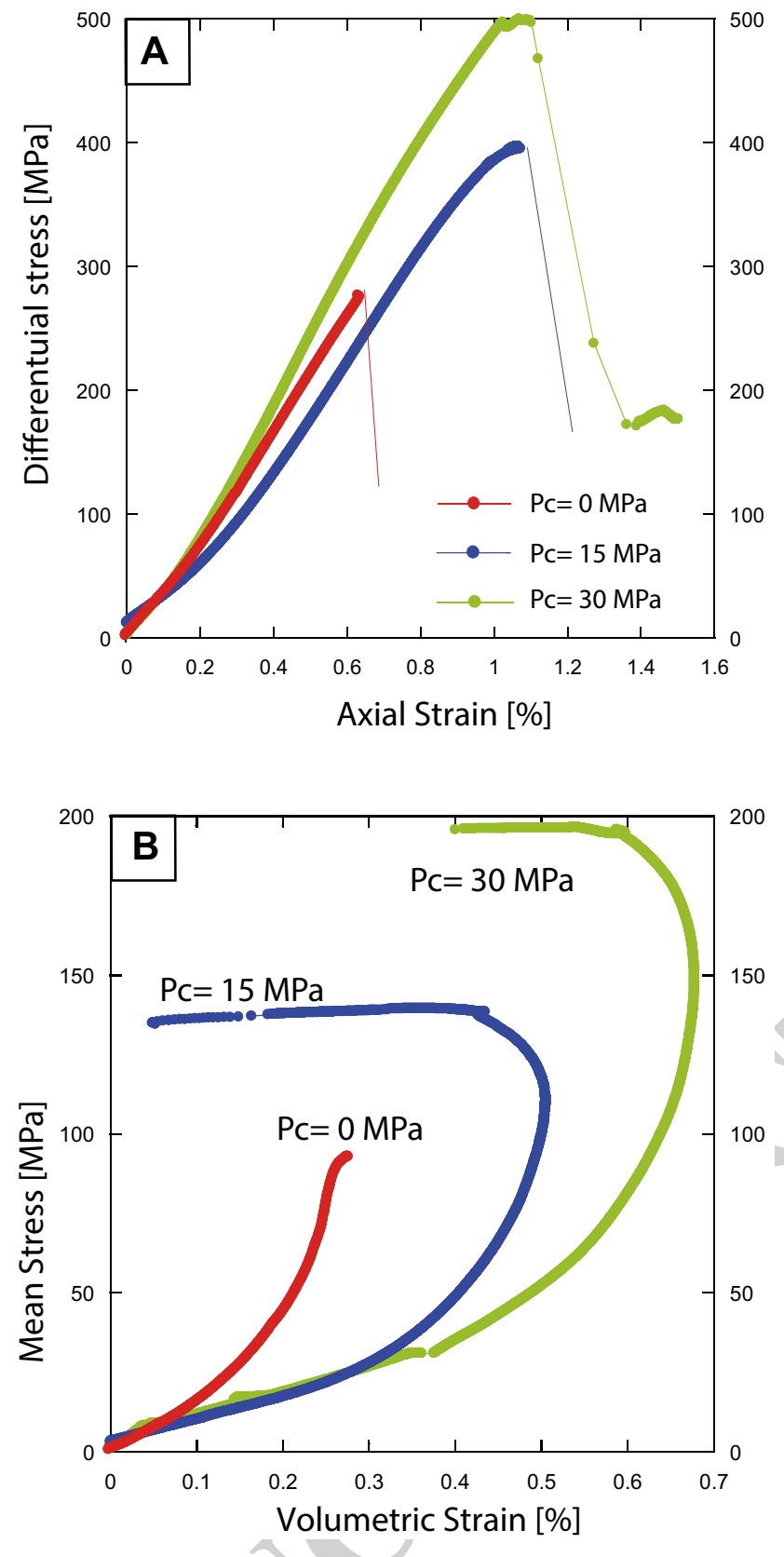

Fig. 8 Conventional triaxial experiments on heat treated (at $930{ }^{\circ} \mathrm{C}$ ) andesite samples under dry condition. a Differential stress versus axial strain under confining pressure of $0 \mathrm{MPa}, 15 \mathrm{MPa}$ and $30 \mathrm{MPa}$. b Mean stress versus volumetric strain

thermoelasticity and fracture mechanics, the total surface of crack S (per unit volume) created during heat treatment and due to different thermal expansion of minerals is given by (Davidge and Green 1968; Fredrich and Wong 1986):

$S=\frac{1}{8 G_{I C}}\left[\frac{E}{1-2 v}\right](\Delta \alpha \Delta T)^{2}$

where $E$ is Young's modulus of the (intact) andesite ( $E=64.7$ $\mathrm{GPa}), v$ is Poisson's ratio of intact andesite $(v=0.28)$ and
$\Delta \alpha$ is the thermal expansion contrast between plagioclase and quartz/tridymite or glass, which can be estimated as $14 \times 10^{-6} /{ }^{\circ} \mathrm{C} . \Delta T$ is the temperature of the heat treatment. $G_{\mathrm{IC}}$ is the energy release rate of andesite under mode I and is estimated to be $5-6.5 \mathrm{~J} / \mathrm{m}^{2}$ (Fredrich and Wong 1986; Tutluoglu and Keles 2011; Talukdar 2018) In addition, the relationship between the total surface of the crack $S$ and the crack density, $\rho=N l^{3} / V$, is $S=2 \pi \rho / \mathrm{c}$, where c is the mean radius of the crack in the volume $V(l=2 \mathrm{c})$.

Following Wang et al. (2013), and assuming that the average thermal crack size is that of the grain size, $l$, (i.e., $c=l / 2$ ), we can estimate the crack density created (i) in the matrix or (ii) at the interface between the large inclusions and the matrix. In the matrix, grains of plagioclase and quartz/tridymite have an average length of $1 \mu \mathrm{m}$, which leads to a crack density of 0.04-0.053. However, the large inclusions have average lengths of 100-200 $\mu \mathrm{m}$, which lead to crack densities of $0.4-0.53$, values much higher than the crack density generated in the matrix. The estimated initial crack density is $\rho=0.6$ (Fig. 3) for andesite samples heattreated at $930^{\circ} \mathrm{C}$. Note that this figure is out of the range of validity for effective medium theory. However, this value quantitatively indicates a high degree of cracking.

In addition, we can define the aspect ratio $\xi=w / c$, where $W$ is the crack half aperture. The total crack porosity is equal to $\phi=2 \pi \rho \xi$, which is $3.7 \%$ after the heat treatment. This value leads to a crack aspect ratio of approximately $10^{-2}$, an order of magnitude that agrees with those in previous studies (Wang et al. 2013; Adelinet et al. 2011).

\subsubsection{Crack Density and Anisotropy}

The evolution of the crack density during loading can be deduced from the evolution of the elastic P-wave velocities (Fortin et al. 2011). More precisely, assuming a transversely isotropic symmetry, noninteraction and dry conditions, the two components of the crack density tensor can be deduced from the ultrasonic measurements (Gueguen and Kachanov 2011). An alternative and equivalent method is to estimate, from the ultrasonic measurements, the vertical crack density and the randomly oriented crack density (Gueguen and Kachanov 2011; Fortin et al. 2011; Nicolas et al. 2016). See also the appendix "Crack density inversion method-Transversely isotropic symmetry".

The evolution of the crack density for the experiments performed at $\mathrm{Pc}=30 \mathrm{MPa}$ on the non-heat-treated samples and heat-treated samples is shown in Fig. 10. In the non-heat treated samples, the crack density evolution is directly correlated with the initiation and propagation of cracks at the onset of dilatancy. These induced cracks are mainly axial, and the density of the randomly oriented cracks is almost equal to zero during the loading (Fig. 10a).
467

\begin{tabular}{|l|l|l|l|l|}
\hline Journal : Large $\mathbf{6 0 3}$ & Article No : 1785 & Pages : 20 & MS Code : RMRE-D-18-00808 & Dispatch : 19-3-2019 \\
\hline
\end{tabular}



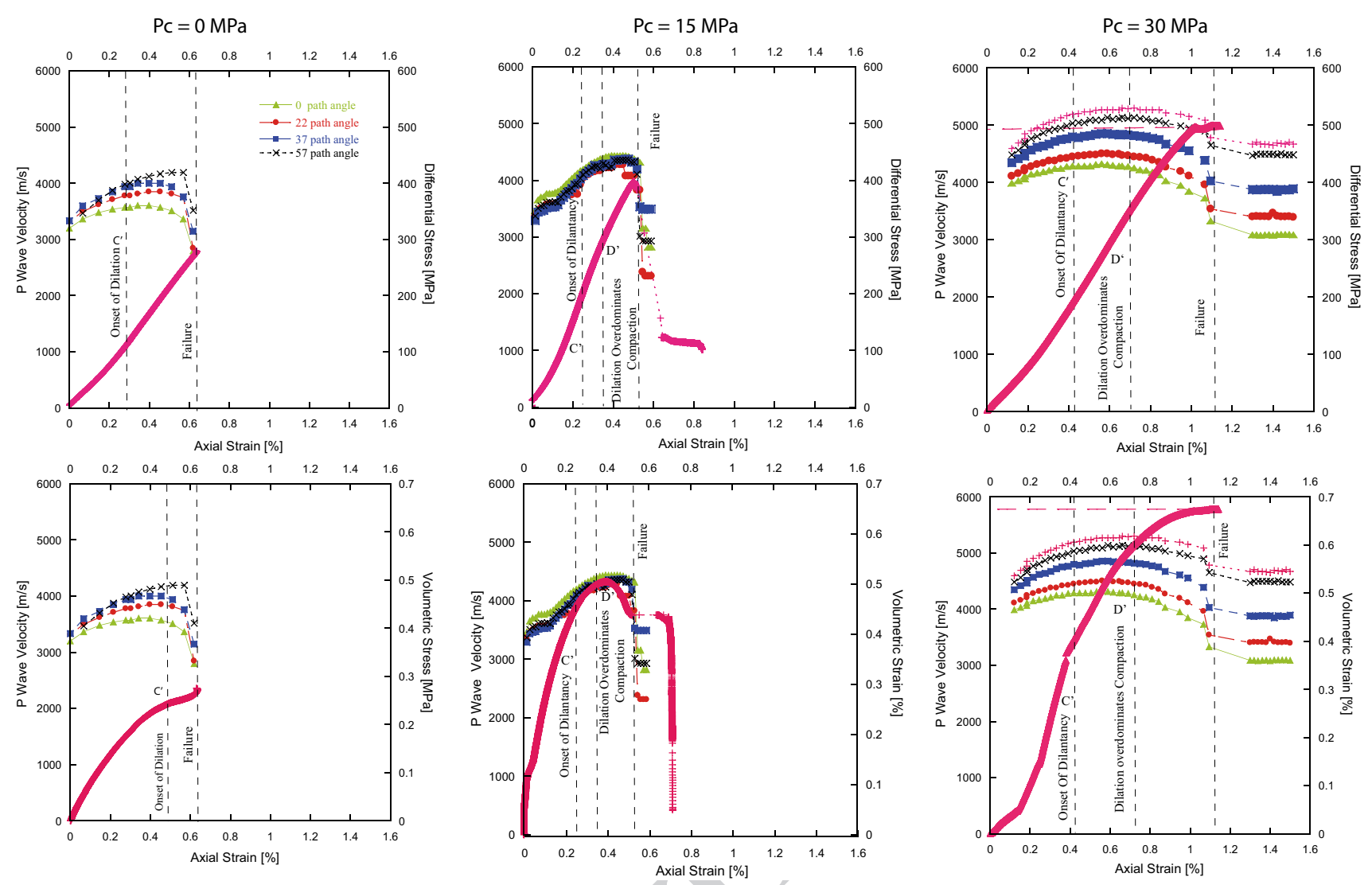

Fig. 9 P-wave velocity and differential stress measured during triaxial deformation experiments on heat treated (at $930{ }^{\circ} \mathrm{C}$ ) andesite samples under confining pressure of $0 \mathrm{MPa}, 15 \mathrm{MPa}$ and $30 \mathrm{MPa}$. P-wave velocity and differential stress are plotted versus axial strain. P-wave

velocity and volumetric strain are plotted versus axial strain. The point C' indicates the onset of dilatancy, D' indicates dilation over dominates compaction, failure is marked
In heat-treated samples that contain pre-existing thermal cracks, the randomly oriented crack density starts to decrease at the beginning of differential loading, while the axial crack density increases significantly beyond the onset of dilatancy. The axial crack density in Fig. 10b increases even before the onset of dilatancy. As the axial stress increases, the pre-existing randomly oriented cracks close while the axial cracks open. Crack opening causes a decrease in the P-wave velocity and an increase in the crack density.

Note that the crack density inverted in Fig. 3 is based on the measurement of the P-wave velocity at ambient pressure, whereas the crack density inverted in Fig. 10 is based on the measurement of the P-wave velocity under a confining pressure of $30 \mathrm{MPa}$. Due to the effect of pressure, the P-wave velocities increase as the pressure increases; thus, the crack density decreases as the confining pressure increases. This phenomenon explains why the initial crack density in Fig. 10 is lower than that reported in Fig. 3.

\subsection{Effect of Heat Treatment on The Microstructure: Partial Melting}

The question is: where does the melt go? Fig. 11 shows that the melt seals some cracks, especially the cracks with the largest apertures. We also observe that bubbles are distributed in the melt in agreement with the observations of Simmons and Richter (1976), Swanenberg (1980), and Roedder (1981), indicating that the bonding strength is recovered. The melt flows into the cracks, and as it cools, the glass bonds the two surfaces of cracks. Bubbles are clearly observed in the SEM (Fig. 6). Since the spherical bubbles represent relatively stable pore shapes, we refer to the bubble planes as being strength recovered.

SEM and EBSD reveal that the melt content is an amorphous phase that contains $\mathrm{Fe}, \mathrm{K}$, and $\mathrm{Mg}$. Partial melting probably results from the presence of smectite, which has lowered melting point of other minerals. Indeed, the melting point of pyroxene and plagioclase is $1400{ }^{\circ} \mathrm{C}$, whereas smectite melts at temperatures of $400-500{ }^{\circ} \mathrm{C}$.

\begin{tabular}{|l|l|l|l|l|}
\hline Journal : Large 603 & Article No : 1785 & Pages : 20 & MS Code : RMRE-D-18-00808 & Dispatch : 19-3-2019 \\
\hline
\end{tabular}




\subsection{Effect of Heat Treatment on Mechanical Strength}

\subsubsection{Effect on The Onset and Development of Dilatancy}

The stress states at the onset of dilatancy (C') during constant strain rate triaxial deformation experiments of intact and heat-treated andesite samples are plotted in Fig. 12. Heat treatment does not induce any change in the stress state at the onset of dilatancy despite the dramatic increase in damage (crack density). This result can be explained by the fact that $C^{\prime}$ is sensitive to crack nucleation or propagation regardless of the initial crack density.

Wing crack damage models are currently used to quantitatively analyze the dilatancy evolution under axisymmetric loading. Brittle faulting can be modeled by a sliding wing crack model (Cotterell and Rice 1980). Following Ashby and Sammis (1990), wings are expected to start to grow from pre-existing flaws at an axial stress equal to:

$\sigma_{1}=\frac{\left(1+\mu^{2}\right)^{1 / 2}+\mu}{\left(1+\mu^{2}\right)^{1 / 2}-\mu} \sigma_{3}+\frac{\sqrt{3}}{\left(1+\mu^{2}\right)^{1 / 2}-\mu} \frac{K_{I C}}{\sqrt{\pi a}}$

where $\sigma_{1}$ and $\sigma_{3}$ are the maximum and minimum principal stresses, $\mu$ is the friction coefficient on pre-existing flaws, $K_{I C}$ is the fracture toughness and $a$ is the length of pre-existing flaws. Note that this criterion (Eq. 2) is not directly sensitive to the crack density. The length of pre-existing flaws, $a$, is estimated to be in the range of $100-300 \mu \mathrm{m}$, which corresponds to the average length of large inclusions. Fitting the onset of dilatancy for triaxial deformation experiments performed at different confining pressures on intact samples, the friction coefficient $\mu$ is estimated to be equal to 0.57 , and the fracture toughness $K_{\mathrm{IC}}$ is in the range from $1.1 \mathrm{MPa} \mathrm{m}^{1 / 2}$ to $1.9 \mathrm{MPa} \mathrm{m}{ }^{1 / 2}$. The friction coefficient is in good agreement with the mean values found in rocks (Byerlee 1978), and the fracture toughness is in the range of values obtained for andesite (1-2 $\mathrm{MPa} \mathrm{m}^{1 / 2}$ ), as measured by Ouchterlony (1990), Tutluoglu and Keles (2011), and Nara et al. (2012).

The friction coefficient $\mu_{\mathrm{HT}}$ is estimated to be 0.57 , the same value as for non-heat-treated samples. The fracture toughness for heat-treated andesite samples $K_{\mathrm{IC}-\mathrm{HT}}$ is estimated in the range $1-1.7 \mathrm{MPa} \mathrm{m}^{1 / 2}$, values slightly lower than those for non-heat-treated samples.

\subsubsection{Effect on The Peak Strength}

Heat-treated samples of andesite have higher peak stresses than intact samples (Fig. 13).

The 2D damage model previously presented to analyze the onset of dilatancy can also be used to quantitatively model the failure of the samples (Ashby and Sammis 1990;
Kemeny and Cook 1991; Baud et al. 2014; Mallet et al. 2014). This model leads to a brittle failure envelope that can be described as:

$\sigma_{1}=A\left(\mu, D_{0}\right) \sigma_{3}+B\left(\mu, D_{0}\right) \frac{K_{\mathrm{IC}}}{\sqrt{\pi a}}$,

where $A$ and $B$ are constants that depend on the friction coefficient on pre-existing flaws and on the initial damage $\left(D_{0}\right)$ defined as $D_{0}=\frac{4}{3} \pi(\alpha a)^{3} N_{V}$, where $N_{y}$ is the number of sliding cracks initially present. According to the model prediction, peak strength decreases with initial damage, assuming $a$ is a constant, which may seem to contradict our results showing an increase in peak stress after heat treatment despite an increase in initial damage.

However, the previous model is probably too simple for at least two reasons. First, the enhancement of heat-treated sample strength relative to those of intact samples could be related to a crack sealing process. Microstructural observations show that the longest and largest fractures passing through the matrix are sealed. During the temperature increase, partial melting of some minerals occurs, and the melt flowed along the cracks that had already formed first due to thermal stress (This interpretation implies that parameter $a$ is not a constant and is likely to decrease). The melt filled part of the cracks and finally led to amorphous medium filling and sealing of cracks during cooling.

A second reason is that the most dangerous cracks are the longest ones. Crack sealing of the longest cracks implies an effective crack length decrease. The longest cracks are segmented into smaller length cracks. In contrast with elastic moduli, which depend on crack density, the mechanical strength is controlled by the longest cracks.

\section{Conclusions and Perspectives}

This investigation aimed to quantify thermal treatment effects on the microstructure (cracking) and the physical and mechanical properties of andesite. In situ conditions (high temperature) and the presence of fluid might modify our observed results. At elevated temperatures during triaxial deformation, the high temperature range $\left(500-1100{ }^{\circ} \mathrm{C}\right)$ could lead to a brittle-ductile transition and thus more complicated mechanical behavior (Violay et al. 2017).

The main results of this work are as follows:

1. Due to thermal treatment, the P-wave velocity decreases by up to $50 \%$ as the temperature of heat treatment varies from room temperature to $1100{ }^{\circ} \mathrm{C}$. The crack density increases to 0.6 .

2. A clay content as low as $1.5 \%$ in the intact rock leads to partial melting for a temperature of heat treat-
600

\begin{tabular}{|l|l|l|l|l|}
\hline Journal : Large 603 & Article No : 1785 & Pages : 20 & MS Code : RMRE-D-18-00808 & Dispatch : 19-3-2019 \\
\hline
\end{tabular}


A Intact sample $-\mathrm{Pc}=30 \mathrm{MPa}$


B Heat - treated sample $-\mathrm{PC}=30 \mathrm{MPa}$

4Fig. 10 Axial crack density and randomly oriented crack density evolution versus axial strain during triaxial deformation experiments on (a) non-heat-treated andesite samples under confining pressure of $30 \mathrm{MPa}$ and (b) heat-treated (at $930{ }^{\circ} \mathrm{C}$ ) andesite samples under confining pressure of $30 \mathrm{MPa}$ ment $>500{ }^{\circ} \mathrm{C}$. Partial melting modifies the microstructure and the characteristics of the rocks.

3. A small amount of crack sealing changes the distribution of the crack size. The ultrasonic velocity is weakly modified, but the mechanical strength is enhanced.
4. Thermal treatment could have a strengthening effect on a rock depending on the original microstructure of the rock and the mineral content. This result is counterintuitive but might be linked to the presence of clay in the andesite.

Acknowledgements We thank Léa Lévy for help with SEM observation and XRD analysis, and thanks to Dr. Thomas Ferrand and Dr. Sarah Incel for discussion. This work is supported by the French State through the Future Investments funds under GROTREF project, which is a multidisciplinary platform for innovation and demonstration activities for the exploration and development of high geothermal energy in fractured reservoirs.

\section{Crack Sealing in Heat treated andesite at $930{ }^{\circ} \mathrm{C}$}
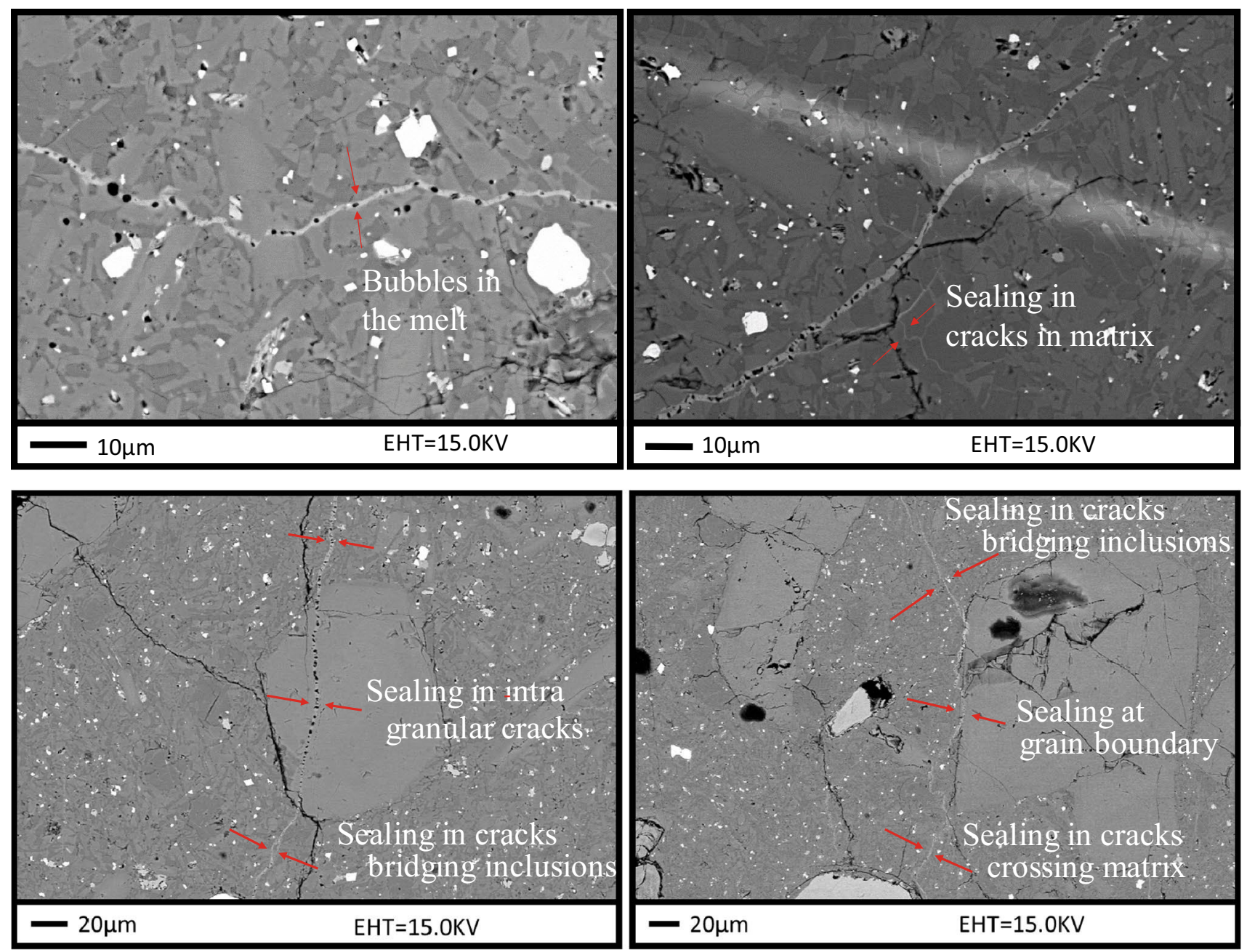

Fig. 11 Crack sealing observed in intergranular cracks. Bubbles observed in the melt which seals the cracks

\begin{tabular}{|l|l|l|l|l|}
\hline Journal : Large 603 & Article No : 1785 & Pages : 20 & MS Code : RMRE-D-18-00808 & Dispatch : 19-3-2019 \\
\hline
\end{tabular}




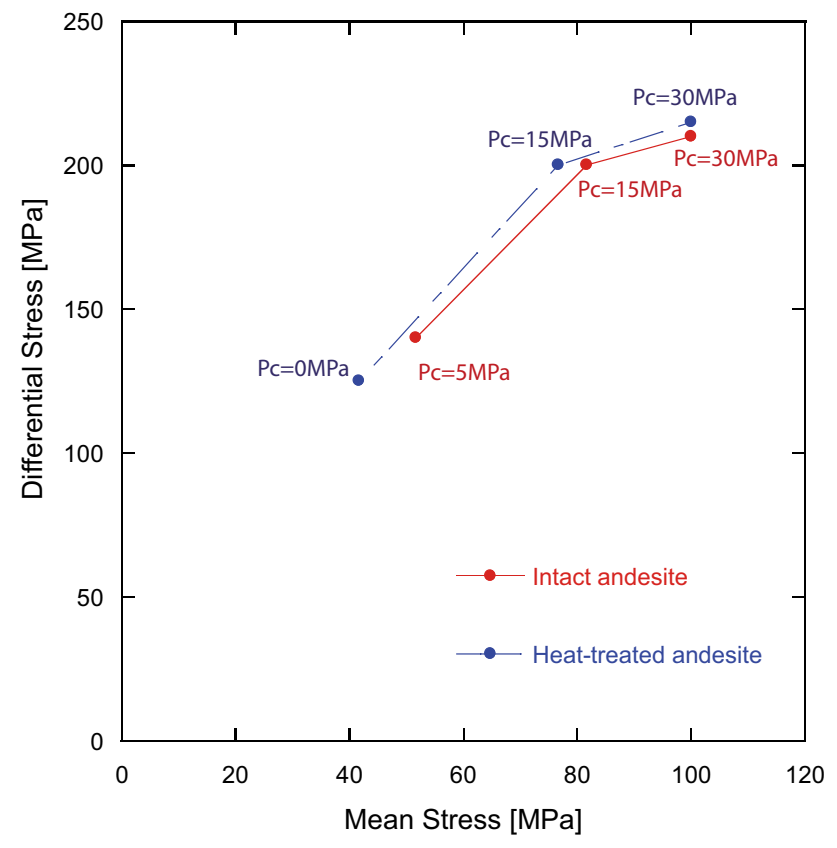

Fig. 12 Stress states C' (onset of dilatancy) in non-heat-treated samples and heat-treated samples (at $930^{\circ} \mathrm{C}$ )

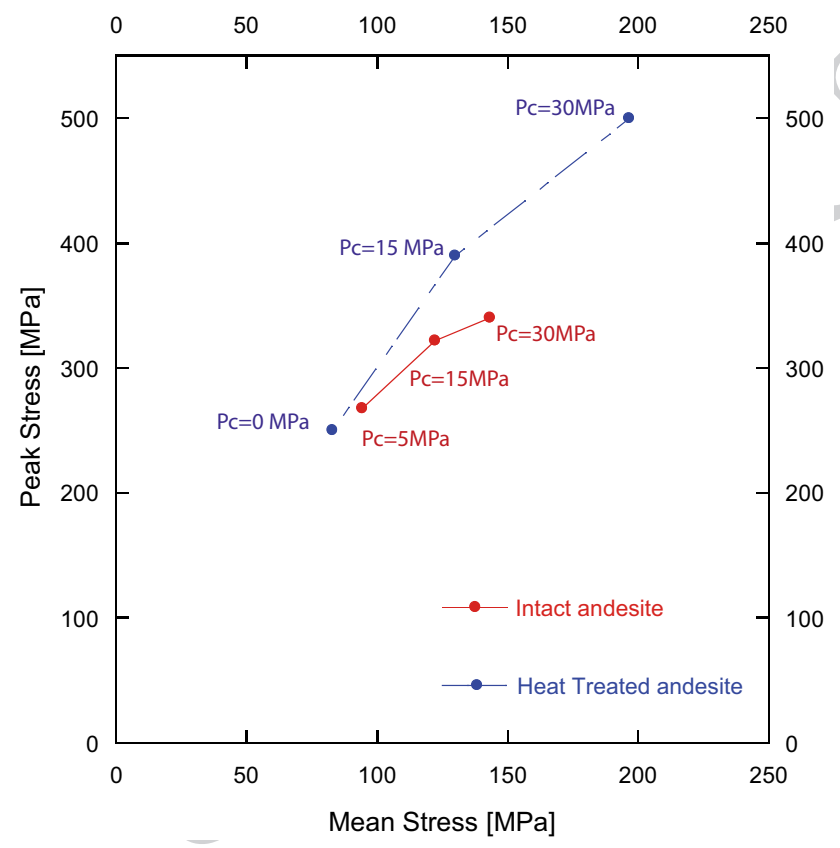

Fig. 13 Stress states at failure in non-heat-treated samples and heattreated samples (at $930{ }^{\circ} \mathrm{C}$ )

\section{Appendix 1}

Appendix 2: List of Symbols

635

$K \quad$ Effective bulk modulus 636

$K_{\theta} \quad$ Effective shear modulus $O$

$\varepsilon_{\forall} \quad$ Volumetric strain 638

$G \quad$ Bulk moduli- of the eraek-free matrix $\Omega 639$

$G_{o} \quad$ Total surface of crack $\Omega \quad 640$

$\phi \quad$ Shear moduli of the erack free matrix 641

$\rho_{c} \quad$ Scalar crack density 642

$v_{o} \quad$ Poisson's ratio of the crack-free matrix 643

$n \quad$ Unit normal to a crack 644

nn Dyadic product 645

$\begin{array}{lll}\rho_{i} & \text { The randomly oriented crack density } & 646\end{array}$

$\rho_{v} \quad$ The axial crack density induced by the mechanical 647 loading

C Stiffness tensor

$E_{0} \quad$ Young's modulus of the crack-free matrix

$v_{\theta} \quad$ Poissen's ratio of the crack free matrix

$\phi \quad$ Propagation angles $\phi$

$V_{p}(\phi)$ Wave phase velocities along the propagation angles

$M \quad \phi \quad$ The least square value

$K$ Effective bulk modulus

Crack Density Inversion Method: Isotropic Case

In the noninteraction approximation, the effective elastic properties in the dry case are given by Bristow 1960:

659

$\frac{K_{o}}{K}=1+\rho_{c} \frac{h}{1-2 v_{o}}\left(1-\frac{v_{o}}{2}\right)$

660

661

$\frac{G_{o}}{G}=1+\rho_{c} \frac{h}{1+v_{o}}\left(1-\frac{v_{o}}{5}\right)$

$K$ is the effective bulk modulus that can be directly inverted from a combination of the P- and S-wave velocities, and $G$ is the effective shear modulus that can be directly inverted from the $\mathrm{S}$-wave velocities. $K_{o}$ and $G_{o}$ are the bulk and shear moduli of the crack-free matrix, and $v_{o}$ is the corresponding Poisson's ratio of this state. The value $\mathrm{h}$ is a factor given by $h=\frac{16\left(1-v_{o}^{2}\right)}{9\left(1-\frac{v_{o}}{2}\right)}$

\begin{tabular}{|l|l|l|l|l|}
\hline Journal : Large 603 & Article No : 1785 & Pages : 20 & MS Code : RMRE-D-18-00808 & Dispatch : 19-3-2019 \\
\hline
\end{tabular}


Fig. 14 Triaxial cell installed at École Normale Supérieure (Adapted from Ougier-Simonin et al. 2010, 2011)
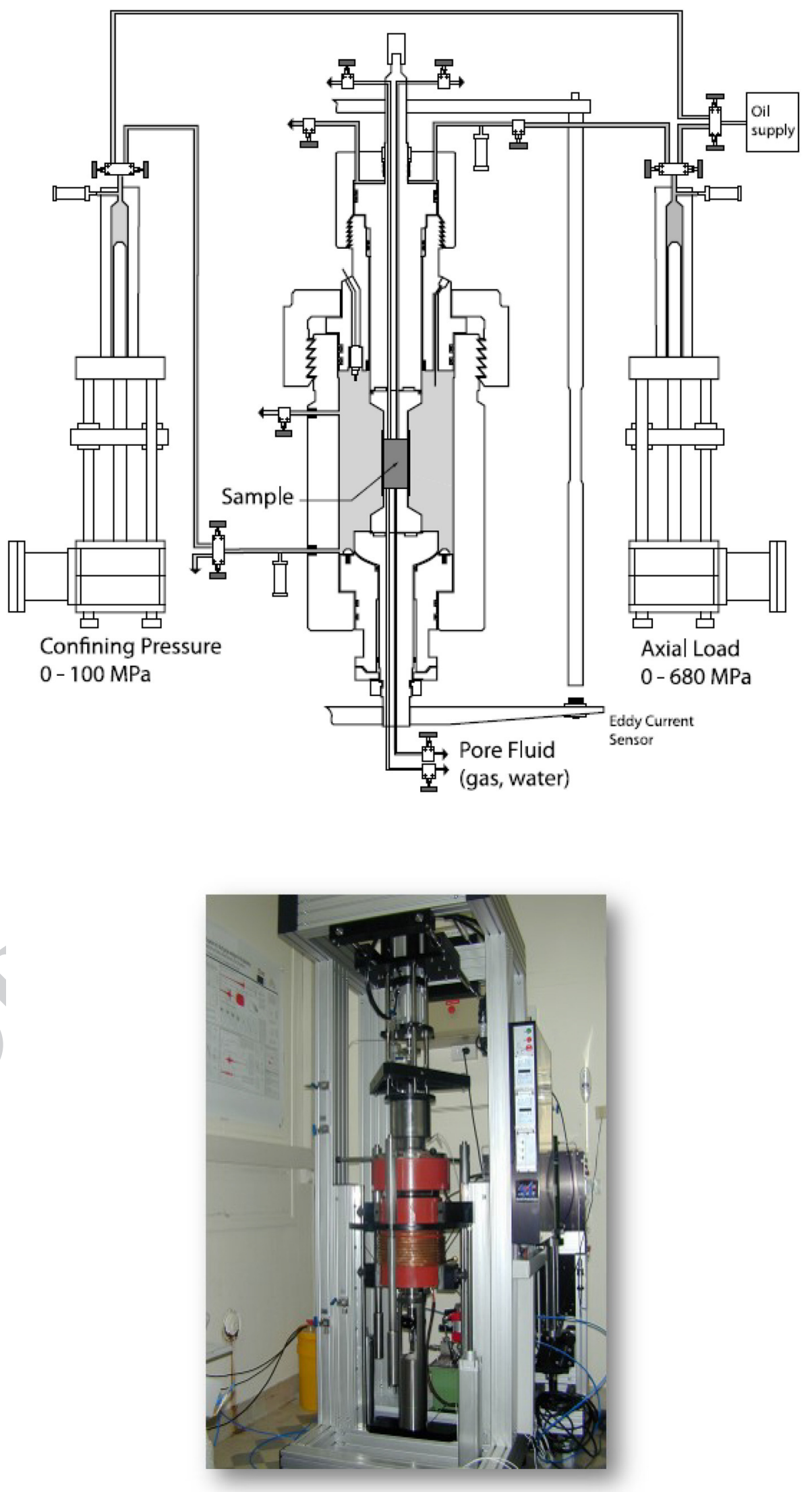
with the minimum distance between predicted and measured velocities (Fortin et al. 2011; Nicolas et al. 2016).

\section{References}

Adelinet M, Fortin J, Guéguen Y (2011) Dispersion of elastic moduli in a porous-cracked rock: theoretical predictions for squirt-flow. Tectonophysics 503(1-2):173-181

Ashby MFA, Hallam SD (1986) The failure of brittle solids containing small cracks under compressive stress states. Acta Metall 34(3):497-510

Ashby MF, Sammis CG (1990) The damage mechanics of brittle solids in compression. Pure appl Geophys 133(3):489-521

Baud P, Wong TF, Zhu W (2014) Effects of porosity and crack density on the compressive strength of rocks. Int J Rock Mech Min Sci 67:202-211

Bouysse P, Westercamp D (1990) Subduction of Atlantic aseismic ridges and Late Cenozoic evolution of the Lesser Antilles island arc. Tectonophysics 175(4):349-380

Bowen NL (1912) The order of crystallization in igneous rocks. J Geol 20(5):457-468

Bowen NL (1913) The melting phenomena of the plagioclase feldspars. Am J Sci 210:577-599

Brace WF, Pauling BW, Scholz C (1966) Dilatancy in fracture of crystalline rock. J Geophys Res 71:3939. 9

Brantut N, Sulem J, Schubnel A (2011) Effect of dehydration reactions on earthquake nucleation: stable sliding, slow transients, and unstable slip. J Geophys Res 116(B5):16

Brotons V, Tomás R, Ivorra S, Alarcón JC (2013) Temperature influence on the physical and mechanical properties of a porous rock: San Julian's calcarenite. Eng Geol 167:117-127

Byerlee J (1978) Friction of rocks. Rock friction and earthquake prediction. Birkhäuser, Basel, pp 615-626

Chaki S, Takarli M, Agbodjan WP (2008) Influence of thermal damage on physical properties of a granite rock: porosity, permeability and ultrasonic wave evolutions. Constr Build Mater 22(7):1456-1461

Cotterell B, Rice J (1980) Slightly curved or kinked cracks. Int J Fract 16(2):155-169

Darot M, Reuschlé T (2000) Effect of pore and confining pressures on VP in thermally pre-cracked granites. Geophys Res Lett 27(7):1057-1060

Davidge RW, Green TJ (1968) The strength of two-phase ceramic/glass materials. J Mater Sci 3(6):629-634

Faoro I, Vinciguerra S, Marone C, Elsworth D, Schubnel A (2013) Linking permeability to crack density evolution in thermally stressed rocks under cyclic loading. Geophys Res Lett 40(11):2590-2595

Farquharson J, Heap MJ, Varley NR, Baud P, Reuschlé T (2015) Permeability and porosity relationships of edifice-forming andesites: a combined field and laboratory study. J Volcanol Geoth Res 297:52-68

Faulkner DR, Rutter EH (2003) The effect of temperature, the nature of the pore fluid, and subyield differential stress on the permeability of phyllosilicate-rich fault gouge. J Geophys Res 108(B5):12

Feuillet N, Manighetti I, Tapponnier P (2001) Active arc-transverse normal faulting in Guadeloupe (French Lesser Antilles). Comptes Rendus De L Academie Des Sciences Serie II Fascicule A-Sciences De La Terre Et Des Planetes 333(9):583-590

Feuillet N, Manighetti I, Tapponnier P, Jacques E (2002) Arc parallel extension and localization of volcanic complexes in Guadeloupe, Lesser Antilles. J Geophys Res 107(B12):ETG-E3

Fortin J, Stanchits S, Vinciguerra S, Guéguen Y (2011) Influence of thermal and mechanical cracks on permeability and elastic wave velocities in a basalt from Mt. Etna volcano subjected to elevated pressure. Tectonophysics 503(1-2):60-74

Fredrich JT, Wong TF (1986) Micromechanics of thermally induced cracking in three crustal rocks. J Geophys Res 91(B12):12743-12764

Friedman M, Handin J, Higgs NG, Lantz JR (1979) Strength and ductility of four dry igneous rocks at low pressures and temperatures to partial melting. In: 20th US symposium on rock mechanics (USRMS). American Rock Mechanics Association

Géraud Y (1994) Variations of connected porosity and inferred permeability in a thermally cracked granite. Geophys Res Lett 21(11):979-982

Glover PWJ, Baud P, Darot M, Meredith P, Boon SA, LeRavalec M, Zoussi S, Reuschle T (1995) $\alpha / \beta$ Phase transition in quartz monitored using acoustic emissions. Geophys J Int 120(3):775-782

Greene-Kelly R (1953) Irreversible dehydration in montrnorillonite. Part II Clay Miner Bull 1:52-56

Greil P (2012) Generic principles of crack-healing ceramics. J Adv Ceram 1(4):249-267

Guéguen Y, Dienes J (1989) Transport properties of rocks from statistics and percolation. Math Geol 21(1):1-13

Guéguen Y, Kachanov M (2011) Effective elastic properties of cracked rocks-an overview. In: Leroy YM, Lehner FK (eds) Mechanics of Crustal Rocks. Springer, Berlin, pp. 73-125

Guéguen Y, Sarout J (2009) Crack-induced anisotropy in crustal rocks: predicted dry and fluid-saturated Thomsen's parameters. Phys Earth Planet Int 172(1-2):116-124

Gupta TK (1976) Crack healing and strengthening of thermally shocked alumina. J Am Ceram Soc 59(5-6):259-262

Heap MJ, Kennedy BM (2016) Exploring the scale-dependent permeability of fractured andesite. Earth Planet Sci Lett 447:139-150

Heap MJ, Lavallée Y, Petrakova L, Baud P, Reuschle T, Varley NR, Dingwell DB (2014) Microstructural controls on the physical and mechanical properties of edifice-forming andesites at Volcán de Colima, Mexico. J Geophys Res 119(4):2925-2963

Heap MJ, Farquharson JI, Baud P, Lavallée Y, Reuschlé T (2015) Fracture and compaction of andesite in a volcanic edifice. Bull Volc 77(6):55

Homand-Etienne F, Houpert R (1989) Thermally induced microcracking in granites: characterization and analysis. Int J Rock Mech Min Sci Geomech Abstr 26(2):125-134 (Pergamon)

Jaud P, Lamethe D (1985) The Bouillante geothermal power-plant. Guadeloupe Geotherm 14(2-3):197-205

Kachanov M, Tsukrov I, Shafiro B (1994) Effective moduli of solids with cavities of various shapes. Appl Mech Rev 47(1S):S151-S174

Kant MA, Ammann J, Rossi E, Madonna C, Höser D, Rudolf von Rohr, P (2017) Thermal properties of central are granite for temperatures up to $500{ }^{\circ} \mathrm{C}$ : Irreversible changes due to thermal crack formation. Geophys Res Lett 44(2):771-776

Kemeny JM, Cook NG (1991) Micromechanics of deformation in rocks. In: toughening mechanisms in quasi-brittle materials. Springer, Dordrecht, pp 155-188

Keshavarz M, Pellet FL, Loret B (2010) Damage and changes in mechanical properties of a gabbro thermally loaded up to $1000 \mathrm{C}$. Pure Appl Geophys 167(12):1511-1523

Malek Z, Balek V, Garfinkel-Shweky D, Yariv S (1997) The study of the dehydration and dehydroxylation of smectites by emanation thermal analysis. J Ther Anal 48(1):83-92

Mallet C, Fortin J, Guéguen Y, Bouyer F (2013) Effective elastic properties of cracked solids: an experimental investigation. Int J Fract 182(2):275-282

Mallet C, Fortin J, Guéguen Y, Bouyer F (2014) Evolution of the crack network in glass samples submitted to brittle creep conditions. Int J Fract 190(1-2):111-124 
Nara Y, Morimoto K, Hiroyoshi N, Yoneda T, Kaneko K, Benson PM (2012) Influence of relative humidity on fracture toughness of rock: implications for subcritical crack growth. Int J Solids Struct 49(18):2471-2481

Nasseri MHB, Schubnel A, Young RP (2007) Coupled evolutions of fracture toughness and elastic wave velocities at high crack density in thermally treated Westerly granite. Int J Rock Mech Min Sci 44(4):601-616

Nasseri MHB, Schubnel A, Benson PM, Young RP (2009) Common evolution of mechanical and transport properties in thermally cracked westerly granite at elevated hydrostatic pressure. In Rock Physics and Natural Hazards. Birkhäuser, Basel, (pp. 927-948)

Nemat-Nasser S, Horii H (1982) Compression-induced nonplanar crack extension with application to splitting, exfoliation, and rockburst. J Geophys Res 87(B8):6805-6821

Nichols FA, Mullins WW (1965) Morphological changes of a surface of revolution due to capillarity- induced surface diffusion. J Appl Phys 36:1826-1835

Nicolas A, Fortin J, Regnet JB, Dimanov A, Guéguen Y (2016) Brittle and semi-brittle behaviours of a carbonate rock: influence of water and temperature. Geophys J Int 206(1):438-456

Ouchterlony F (1990) Fracture toughness testing of rock with core based specimens. Eng Fract Mech 35(1-3):351-366

Ougier-Simonin DEPA (2010) Characterisation of hydraulic fractures in limestones using X-ray microtomography. Adv X-ray Tomogr Geomater 118:221

Ougier-Simonin A, Fortin J, Guéguen Y, Schubnel A, Bouyer F (2011) Cracks in glass under triaxial conditions. Int J Eng Sci 49(1):105-121

Roedder E (1981) Origin of fluid inclusions and changes that occur after trapping. Fluid Incl 6:101-137

Russel J, Famer V (1964) Infra-red spectroscopic study of the dehydration of montmorillonite and saponite. Clay Min Bull 5:443

Sayers CM, Kachanov M (1995) Microcrack-induced elastic wave anisotropy of brittle rocks. J Geophys Res 100(B3):4149-4156

Schubnel A, Benson PM, Thompson BD, Hazzard JF, Young RP (2006) Quantifying damage, saturation and anisotropy in cracked rocks by inverting elastic wave velocities. In Rock damage and fluid transport, part I. Birkhäuser, Basel, pp. 947-973

Schubnel A, Thompson BD, Fortin J, Guéguen Y, Young RP (2007) Fluid-induced rupture experiment on Fontainebleau sandstone: Premonitory activity, rupture propagation, and aftershocks. Geophys Res Lett 34(19):5

Sengun N (2014) Influence of thermal damage on the physical and mechanical properties of carbonate rocks. Arab J Geosci 7(12):5543-5551

Simmons G, Richter D (1976) Microcracks in rocks. Phys Chem Miner Rocks 100 105-137

Siratovich PA, Heap MJ, Villenueve MC, Cole JW, Reuschlé T (2014) Physical property relationships of the Rotokawa Andesite, a significant geothermal reservoir rock in the Taupo Volcanic Zone, New Zealand. Geotherm Energy 2(1):10

Siratovich P, Cole J, Heap M, Villeneuve M, Reuschlé T, Swanson K, Kennedy B, Gravley D, Lavallée Y (2015) Experimental thermal stimulation of the Rotokawa Andesite

Smith DL, Evans B (1984) Diffusional crack healing in quartz. J Geophys Res 89:4125-4136
Sprunt ES, Nur A (1979) Micro-cracks and healing in granites: new evidence from cathodoluminescence. Science 205:495-497

Swanenberg HEC (1980) Fluid inclusions in high-grade metamorphic rocks from SW Norway (Doctoral dissertation, Utrecht University)

Talukdar M, Roy D, Singh TN (2018) Correlating mode-I fracture toughness and mechanical properties of heat-treated crystalline rocks. J Rock Mech Geotech Eng 10(1):91-101

Thompson BD, Young RP, Lockner DA (2005) Observations of premonitory acoustic emission and slip nucleation during a stick slip experiment in smooth faulted Westerly granite. Geophys Res Lett 32(10):6

Thompson BD, Young RP, Lockner DA (2006) Fracture in Westerly granite under AE feedback and constant strain rate loading: nucleation, quasi-static propagation, and the transition to unstable fracture propagation. Pure applied geophysics 163(5-6):995-1019

Trias R, Ménez B, Le Campion P, Zivanovic Y, Recourt L, Lecoeuvre A, Schmitt-Kopplin P, Uhl J, Gislason S, Alfreðsson H, Mesfin K, Snæbjörnsdóttir S, Aradóttir E, Gunnarsson I, Matter J, Stute M, Oelkers E, Gérard E (2017) High reactivity of deep biota under anthropogenic $\mathrm{CO} 2$ injection into basalt. Nat Commun. https:// doi.org/10.1038/s41467-017-01288-8

Tutluoglu L, Keles C (2011) Mode I fracture toughness determination with straight notched disk bending method. Int J Rock Mech Min Sci 48(8):1248-1261

Villemant B, Komorowski JC, Dessert C, Michel A, Crispi O, Hammouya G, Beauducel F, De Chabalier JB (2014) Evidence for a new shallow magma intrusion at La Soufrière of Guadeloupe (Lesser Antilles): insights from long-term geochemical monitoring of halogen-rich hydrothermal fluids. J Volcanol Geoth Res 285:247-277

Vinciguerra S, Trovato C, Meredith PG, Benson PM (2005) Relating seismic velocities, thermal cracking and permeability in Mt. Etna and Iceland basalts. Int J Rock Mech Min Sci 42(7-8):900-910

Violay M, Heap M, Acosta M, Madonna C (2017) Porosity evolution at the brittle ductile transition in the continental crust: implications for deep hydro-geothermal circulation. Sci Rep. https://doi. org/10.1038/s41598-017-08108-5

Walsh JB (1965) The effect of cracks on the uniaxial elastic compression of rocks. J Geophys Res 70(2):399-411

Wang XQ, Schubnel A, Fortin J, Guéguen Y, Ge HK (2013) Physical properties and brittle strength of thermally cracked granite under confinement. J Geophys Res 118(12):6099-6112

Wong TF, Fredrich JT, Gwanmesia GD (1989) Crack aperture statistics and pore space fractal geometry of Westerly granite and Rutland quartzite: Implications for an elastic contact model of rock compressibility. J Geophys Res 94(B8):10267-10278

Wong TF, Wong RH, Chau KT, Tang CA (2006) Microcrack statistics, Weibull distribution and micromechanical modeling of compressive failure in rock. Mech Mater 38(7):664-681

Zhu W, Baud P, Vinciguerra S, Wong TF (2016) Micromechanics of brittle faulting and cataclastic flow in Mount Etna basalt. J Geophys Res 121(6):4268-4289

Publisher's Note Springer Nature remains neutral with regard to jurisdictional claims in published maps and institutional affiliations. 